\title{
The Impact of Tax Refund Delays on the Experience of Hardship Among Lower-Income Households
}

\author{
O. Kondratjeva' ${ }^{1}$ S. P. Roll ${ }^{2} \cdot$ M. Despard ${ }^{3} \cdot$ M. Grinstein-Weiss ${ }^{2}$
}

Received: 21 April 2021 / Accepted: 28 December 2021 / Published online: 10 February 2022

(c) The Author(s), under exclusive licence to Springer Science+Business Media, LLC, part of Springer Nature 2022

\begin{abstract}
The Earned Income Tax Credit (EITC) provides substantial financial support to lowincome workers in the USA, yet around a quarter of EITC payments are estimated to be erroneous or fraudulent. Beginning in 2017, the Protecting Americans from Tax Hikes Act of 2015 requires the Internal Revenue Service to spend additional time processing early EITC claims, delaying the issuance of tax refunds. Leveraging unique data, this paper investigates how delayed tax refunds affected the experience of hardship and unsecured debt among EITC recipients. Results indicate that early filers experienced increased food insecurity relative to later filers after the implementation of the refund delay.
\end{abstract}

Keywords Tax refund delay · PATH Act · Earned Income Tax Credit · Food insecurity · Unsecured debt

JEL Classification D10 $\cdot \mathrm{G} 50 \cdot \mathrm{H} 24 \cdot \mathrm{I} 38$

Annual tax filing is an extremely common experience in the USA; almost 153 million individual income tax returns were filed in 2018. Most individuals and married couples in the USA are required to file federal income taxes to report their income and determine whether they owe taxes to the federal government. Yet almost $80 \%$ of households do not owe taxes but receive a tax refund (Internal Revenue Service, 2019b) as a result of having paid too

S. P. Roll

Stephen.roll@wustl.edu

O. Kondratjeva

okondratjeva@esd.wa.gov

M. Despard

mdespard@uncg.edu

M. Grinstein-Weiss

michalgw@wustl.edu

1 Employment Security Department, Olympia, WA, USA

2 Social Policy Institute, Brown School, Washington University in St. Louis, St. Louis, MO, USA

3 Department of Social Work, University of North Carolina at Greensboro, Greensboro, NC, USA 
much in income taxes during the year and/or because they qualified for tax credits, such as the Child Tax Credit and Earned Income Tax Credit (EITC).

Tax refunds are especially important for lower-income tax filers because they often represent the single largest payment they will receive all year (Morduch \& Schneider, 2017; Roll et al., 2018) and thus are an important source of consumption support. Lower-income households use refunds for many purposes: to build savings and pay down debt (Despard et al., 2015; Grinstein-Weiss et al., 2015; Mendenhall et al., 2012; Sykes et al., 2015), getting caught up on overdue bills, making home or car repairs, and making large purchases (Mendenhall et al., 2012; Morduch \& Schneider, 2017; Shaefer et al., 2013; Sykes et al., 2015; Tach \& Greene, 2014).

Tax refunds can be especially valuable for lower-income households due to the receipt of the federal EITC, which functionally operates as a wage subsidy for these households. For example, in the 2019 tax year, the maximum benefit for a Head of Household filer with three or more children and $\$ 15000$ in employment income was $\$ 6,557$, or $44 \%$ of their earned income. Because it comprises such a substantial proportion of their yearly income, EITC-eligible recipients often file their annual tax returns as early as possible.

Prior to the 2017 tax season, tax filers did not have long to wait to receive their refunds; they could often expect to receive their refunds within seven to 10 days if they filed electronically and opted to receive their refund via direct deposit. Yet, starting with the 2017 tax season, a newly implemented tax law-the Protecting Americans from Tax Hikes Act (PATH Act) of 2015-requires the Internal Revenue Service (IRS) to provide more time to review and verify wage income to help detect and reduce fraudulent or erroneous EITC and Additional Child Tax Credit (ACTC) claims. Under the PATH Act rule, the IRS began withholding refunds until at least February 15 for filers claiming the EITC or the ACTC, effectively delaying the receipt of refunds until at least late February, which could be a delay of three to four weeks for some filers.

The impetus for the PATH Act was the discovery that about a quarter of EITC payments were made improperly in 2017 and that the IRS was out of compliance with the Improper Payments Elimination and Recovery Act (IPERA) of 2010 (Treasury Inspector General for Tax Administration, 2018). Following the implementation of the PATH Act, the IRS had delayed almost $\$ 58$ billion in refunds from 10.7 million tax returns of filers who claimed the EITC and/or ACTC by February 15 of the 2019 tax season. By February 23, 2019, the IRS identified 3,529 returns $(0.03 \%$ of delayed returns) it determined to contain fraudulent EITC and/or ACTC claims, blocking the allocation of $\$ 12.2$ million in fraudulent refunds $(0.02 \%$ of delayed refunds) (Treasury Inspector General for Tax Administration, 2019). Thus, though millions of refunds were delayed, the actual number fraudulent payments prevented through this delay was reduced a very small fraction of the total. To put these fraudulent refund payments in perspective, $16 \%$ of federal income tax obligations (an average of over $\$ 400$ billion a year) go unpaid due to intentional and unintentional evasion (Gale \& Krupkin, 2019).

Thus, the newly implemented refund delays appear to have effectively interdicted a mere fraction of total improper EITC and ACTC payments. The question, therefore, is whether a small rate of fraud detection through the IRS' refund delays under the PATH Act is worth delaying refunds that support consumption for lower-income households. Waiting for four weeks to receive refunds may seem insignificant, yet a study found that $80 \%$ of lowerincome tax filers experienced material hardship in the months just prior to tax filing and half said a refund delay would negatively affect their finances (Maag et al., 2016). Given this, it is unsurprising that $60-70 \%$ of EITC/ACTC filers in one sample of low-income tax filers filed their taxes within the first few weeks after the start of tax filing (Maag et al., 
2016). Delays may force these households to decrease their consumption, which may lead to increased material hardship and/or increase their borrowing.

The purpose of this study is, therefore, to examine the extent to which delayed refunds may have unintended consequences with respect to material hardship and the accumulation of unsecured debt among lower-income households. To accomplish this, we leveraged unique administrative and survey data and employed a difference-in-differences approach as an identification strategy. We limited the sample to EITC recipients and relied on the time discontinuity in the new rule's dates to identify early filers (the treatment group) and non-early filers (the comparison group) in 2016 (the pre-treatment period) and 2017 (the post-treatment period). We then compared the changes in outcomes over time among EITC recipients in the treatment group relative to those in the comparison group.

Several key findings emerged from the analysis. First, tax filing patterns appeared similar in 2016 and 2017, signalling the lack of changes in filing behaviours among tax filers after the new reform. Second, the incidence of food insecurity increased among early EITC filers relative to later EITC filers following the implementation of the PATH Act. The magnitude of these negative effects appeared larger for households with greater financial vulnerability. Given the statutory intent of the EITC to boost incomes and lift families out of poverty, our findings can help policymakers assess the tradeoffs between this goal and their aim to eliminate fraud and errors and reduce improper payments.

\section{Background}

\section{The Earned Income Tax Credit and Household Financial Security}

The dollar value of the EITC can be substantial-The average value of the EITC was $\$ 2,476$ in the 2018 tax year (Internal Revenue Service, 2018a). However, the value of this credit depends heavily on the income and composition of a household: Those without qualifying children could receive a maximum EITC of $\$ 519$, while households with three or more qualifying children could receive a maximum credit of $\$ 6,431$ in the 2018 tax year. Figure 1 outlines the structure of the credit, which increases with every additional dollar a qualifying household earns until reaching a maximum (the "phase-in" range), remains constant over a set income range, and then begins to decline once a household's income exceeds a given threshold (the "phase-out" range).

The generosity of the EITC makes it one of the most robust antipoverty programmes in the USA; in 2017, the EITC lifted almost six million people (including three million children) out of poverty (Center on Budget \& Policy Priorities, 2019). Other research has found the EITC effective in raising incomes and reducing poverty (Gundersen \& Ziliak, 2004; Hardy et al., 2018; Hoynes \& Patel, 2018). A large body of research has evaluated the relationship between the EITC and household financial security outcomes. This research demonstrates that the receipt of the credit is integral in various ways to the lives and finances of lower-income households. In terms of financial outcomes, the EITC has been shown to lead to higher rates of labour force participation and reduced poverty rates (Eissa \& Liebman, 1996; Ellwood, 2000; Gundersen \& Ziliak, 2004; Hotz et al., 2006; Hoynes \& Patel, 2018; Meyer, 2010; Meyer \& Rosenbaum, 2001), as well as improvements in household balance sheet metrics like increased savings and reduced unsecured debt (Jones \& Michelmore, 2018; Shaefer et al., 2013). Through careful exploration of the finances of lower-income households, 


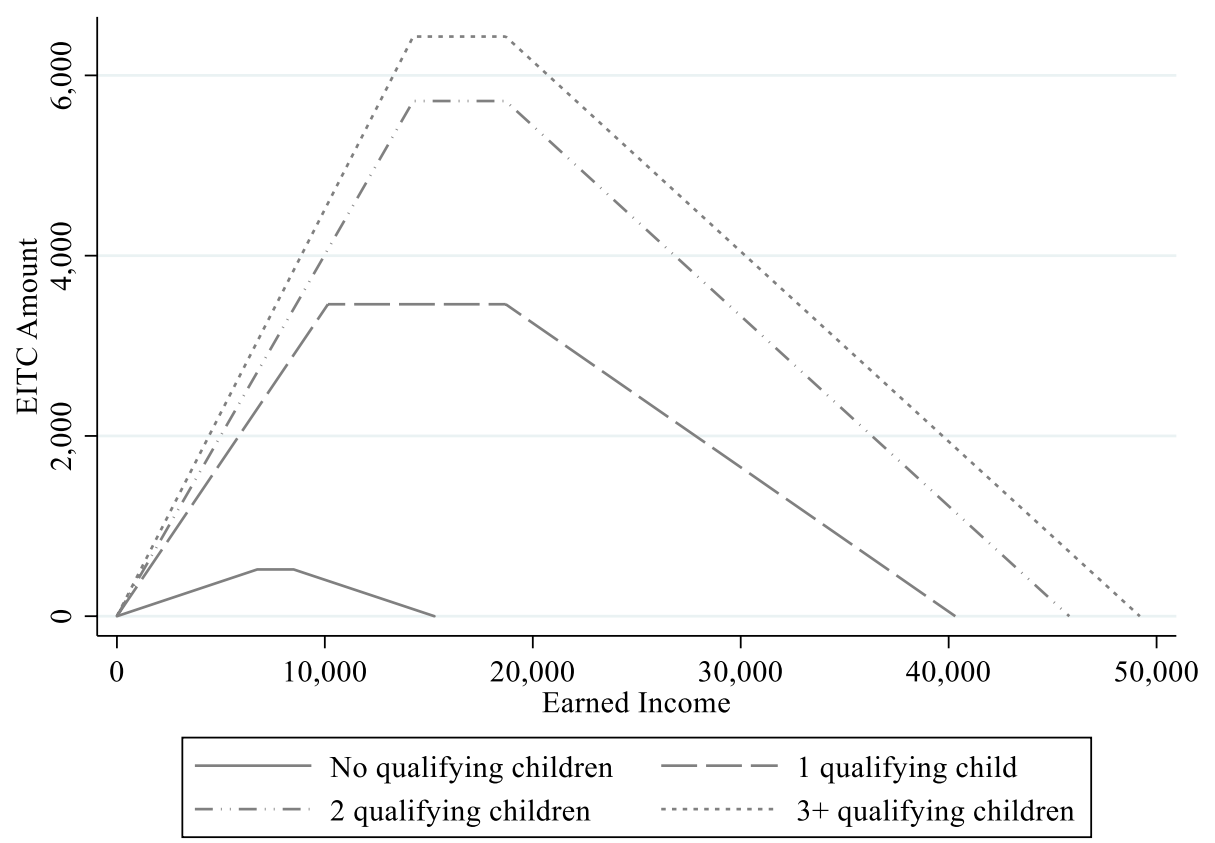

Fig. 1 Schedule of EITC benefits (2018 tax year). Notes: Authors' calculations. Figure assumes federal benefits for individuals filing as single, head of household, or qualifying widowed

Morduch and Schneider (2017) found that these households use certain cash flow management strategies with their refunds. The authors describe one woman who borrowed money from her mother each month to cover expenses prior to receiving her refund, repaying her mother when she received her refund. A couple described how waiting to receive a refund helped them set aside money and keep it out of reach, a finding similar to Romich and Weisner (2000) who found that recipients prefer this "forced savings" mechanism of receiving lump sum refunds.

Mendenhall et al. (2012) found that $46 \%$ of refunds were allocated for current consumption purposes (e.g., groceries, child expenses, car repair), 36\% to get caught up on bills and reduce debt, and $19 \%$ for saving, education, and home purchase or improvement. In a related study, Sykes et al. (2015) found four themes from in-depth interviews that characterized recipients' perceptions of the EITC: relief, enhanced consumption, upward mobility, and social inclusion. While consumption was a key purpose of the credit, recipients also regarded the EITC as a reward for work, an opportunity to plan for the future, and a chance to meet wants as well as needs. Recipients also felt that receiving the credit boosted feelings of self-worth and dignity.

The receipt of the EITC is also associated with an array of secondary effects on households that have implications for both their short- and long-term well-being, including improved health and nutrition outcomes (Averett \& Wang, 2013; Evans \& Garthwaite, 2014; Hoynes et al., 2015; McGranahan \& Schanzenbach, 2013; Rehkopf et al., 2014), and improved educational outcomes (Dahl \& Lochner, 2012; Manoli \& Turner, 2018). 


\section{Financial Precarity in Low-Income Households}

The EITC is particularly valuable for lower-income households given the relatively high degree of budgetary constraints, financial precarity, and hardship they experience. As stated above, the receipt of the tax refund is one of the few times during the year that many lower-income households can build their savings, particularly when their refund is bolstered through the receipt of large credits like the EITC. Building savings is important for lower-income households so they have resources to smooth consumption amidst income and expense volatility (Morduch \& Schneider, 2017) and to mitigate financial emergencies. A nationally representative survey found that two-thirds of lower-income households (those making under $\$ 40000$ a year) could not handle a modest emergency expense using liquid savings or a credit card they could pay off within a month (Board of Governors of the Federal Reserve System, 2016). This low level of liquidity is partially explained by the fact that lower-income households often lack access to banking services offering affordable credit and short-term savings products (Barr, 2007; Blank \& Barr, 2009; Mullainathan \& Shafir, 2009) and are often subject to asset limits in public programmes like the Supplemental Nutrition Assistance Program (SNAP) that disincentivize savings (Neuberger et al., 2006; O'Brien, 2008; Sherraden \& Barr, 2005). Yet perhaps the major reason that lower-income households struggle to save is due to the fact that their budgets are largely consumed by necessary expenditures (Schanzenbach et al., 2016). These households' incomes in a typical month are simply not high enough, relative to their expenses, to save regularly and build a substantial liquidity buffer in the absence of large lump sum payouts like the EITC and, more broadly, the tax refund.

On the other side of the balance sheet, debt burdens are also an issue for many lowerincome households. Debt ownership is a common experience in the USA, with roughly $80 \%$ of adults in 2015 reporting some debt (The Pew Charitable Trusts, 2015). However, lower-income households have debt-to-income ratios that are substantially greater than those in higher-income households and are more likely to have debts in collections (The Aspen Institute, 2018). These relatively high debt burdens in lower-income households are likely affected by similar factors underlying the low rates of savings in these households, such as tight budgets and a lack of affordable banking and credit products. However, evidence also indicates that households experiencing persistent economic scarcity tend to both over-borrow and utilize high-cost credit products in order to manage their present financial obligations (Mullainathan \& Shafir, 2013; Shah et al., 2012). These debt issues have implications for households beyond the balance sheet, as unsustainable debt burdens can lead to broader financial problems including bankruptcy or the deterioration of credit scores, and can cause physical and mental health problems over the long-term (Clayton et al., 2015).

While lower-income households struggle to save for emergencies and manage their debts, they also face a relatively high degree of exposure to financial shocks, such as an unexpected decline in income (e.g., from the loss of a job) or increase in expenses (e.g., from a major car repair or hospitalization). Lower-income households are more likely to experience these shocks (Acs et al., 2009; Chase et al., 2011), which cost an average of between $\$ 1,500$ and $\$ 2,000$ (Collins \& Gjertson, 2013; Searle \& Köppe, 2014) and consume a higher percentage of a lower-income household's budget relative to an equivalent shock in a higher-income household. Experiencing these shocks without an adequate savings or liquidity buffer may result in households experiencing an array of hardships such as housing instability, food insecurity, missing essential bill payments, 
or skipping necessary medical care (Despard et al., 2018; Heflin, 2016; Leete \& Bania, 2010; McKernan et al., 2009; Roll et al., 2018). These hardships, in turn, can have substantial negative implications for downstream household outcomes including child developmental problems (Gershoff et al., 2007; Rauh et al., 2004), the experience of housing insecurity (Desmond \& Kimbro, 2015), and mental and physical health issues (Heflin \& Iceland, 2009; Palar et al., 2016; Sullivan et al., 2008; Whittle et al., 2015).

Given the demonstrated levels of financial precarity in lower-income households, the receipt of the EITC and the tax refund more generally represents an infrequent but often predictable windfall (Epley \& Gneezy, 2007) enabling financial behaviours that may be more difficult through the rest of the year, such as building savings and paying down debts. As such, it provides a means for households to create a financial buffer against future shocks and subsequent hardships, and avoid the debts they have accrued throughout the year from becoming unsustainable.

\section{The PATH Act and Tax Refund Delays}

The PATH Act made several changes to existing tax law, including expanding the Work Opportunity Tax Credit for employers and updating tax filing regulations for wrongfully incarcerated individuals and tax filers using Individual Taxpayer Identification Numbers (IRS, 2019c). Beginning in 2017, the PATH Act also instituted additional safeguards against fraudulent or erroneous claims of the EITC and ACTC on tax returns (Internal Revenue Service, 2018b), which included an additional review period to verify the wages reported on any tax returns claiming the EITC and ACTC. Whereas previously the IRS sent most tax refunds to households 7 to 10 days after tax filing, the PATH Act resulted in the IRS holding the entirety of the tax refund for EITC and ACTC claimants until at least February 15 of the 2017 tax season. However, even though February 15 was the earliest date by which the IRS would release refunds for EITC and ACTC claimants, tax filers were instructed to not expect their refunds until at least the week of February 27 (Internal Revenue Service, 2019a). As the 2017 tax season opened on January 23, this delay meant that early tax filers claiming the EITC or ACTC could potentially expect multiple-week delays in receiving their tax refund, relative to prior years.

There is some evidence of the extent to which tax filers may have experienced these delays. EITC and ACTC filers tend to file their taxes much earlier in the tax season than filers not claiming these credits; $56 \%$ of lower-income online tax filers using free, online tax filing software and claiming the EITC or ACTC filed their taxes before February 15 in 2016 (Maag et al., 2016), suggesting that roughly half of this population could be potentially affected by a multiple-week delay. An analysis of IRS data also indicates that the issuance of EITC and ACTC refunds was delayed by an average of 2 weeks in 2017, relative to prior tax seasons (Aladangady et al., 2018). Additionally, the number of Refund Anticipation Loans (RALs) - which allow tax filers to borrow against their anticipated refund amount in order to get immediate access to the funds promised by the refundalmost quadrupled between 2016 and 2017 (Aladangady et al., 2018). It is possible this increase in RALs was due to households seeking to offset the anticipated delay in refund receipt, though the degree to which this increase in RALs was caused by the refund delay and not some other unrelated factor (e.g., tax preparation companies' marketing efforts) is unclear.

Two studies have investigated the potential and realized impacts of these refund delays on EITC and ACTC claimants. Maag et al. (2016) used a combination of administrative 
tax data and survey data to explore the financial circumstances of the households most likely to be affected by the refund delay: EITC and ACTC claimants with children who filed their taxes early in 2016. Their work shows that over $80 \%$ of these filers experienced extremely high rates of financial hardship such as skipping essential bills or experiencing food insecurity in the months prior to tax filing, about $40 \%$ relied on often costly alternative financial services such as payday loans, $70 \%$ experienced a financial shock such as a decline in income or a major expense, and fewer than half reported being able to manage a modest emergency expense. Survey respondents in this study were also asked about the degree to which a hypothetical one-, two-, three-, or four-week delay in a tax refund would negatively affect their finances, with the length of delay being shown at random to a given respondent. As the length of the delay randomly shown to filers increased, so too did the anticipated effect of the delay; $31 \%$ of respondents said that even a one-week delay would negatively affect their finances at least somewhat, while over $50 \%$ of respondents said a three- or four-week delay would negatively affect their finances to the same degree. Finally, this research also indicates that early-filing EITC and ACTC claimants were largely unaware of the coming delays in tax refund delivery, as $91 \%$ reported not hearing anything about the refund delay in the coming tax season.

In a related study using high-frequency transaction data on credit, debit, and electronic transactions, Aladangady et al. (2018) investigated changes in household consumption spending as a result of the IRS' delay in issuing tax refunds. Their analysis shows that household expenditures among EITC claimants spike during the week of tax refund issuance and remain higher than average over the subsequent two weeks, and they find no evidence that households shift their purchases forward in time because they anticipate receiving a refund in the future. They also find that non-trivial portions of EITC expenditures go to grocery stores and restaurants, as well as at "general merchandise" stores (which are often both grocery and department stores, e.g., Wal-Mart Superstores), indicating that EITC recipients may be delaying essential purchases like food in the absence of the tax refund.

Our study builds on these two pieces of research, as well as the broader literatures on the effects of the tax refund and large tax credits like the EITC. The prior research on tax refunds and the EITC has typically focused on the impacts of receiving the large lump sum payments, while prior work on the refund delay specifically has focused on the anticipated impacts of the delay and household consumption responses to the delay. Our work, by contrast, investigates the realized impacts of even modest delays in the expected large, lump sum payments offered by the tax refund on an array of household outcomes, including the experience of financial and medical hardships, food insecurity, and debt accrual.

\section{Data and Methods}

\section{Data Source}

This paper leverages a unique dataset combining administrative income and tax records with longitudinal survey data on lower-income households collected in 2016 and 2017, corresponding to tax years 2015 and 2016. ${ }^{1}$ Administrative data come from lower-income tax filers who used the free TurboTax Freedom Edition (TTFE) online tax preparation and

\footnotetext{
1 The data were collected through the Refund to Savings (R2S) Initiative, a research collaboration between Washington University in St. Louis, Duke University, and Intuit Inc., the makers of TurboTax.
} 
filing platform to complete their taxes. ${ }^{2}$ While eligibility criteria vary slightly year to year, in 2017 a qualifying tax household had to earn no more than $\$ 33000$ in adjusted gross income (AGI), receive the EITC, or have an active duty military member in their household while earning no more than $\$ 64000$ in AGI. Almost all TTFE filers (over 98.4\% in 2017) qualified for the free tax filing software according to the first two criteria. Administrative tax records include precise information on tax household's filing status, dependents, household income, the amount of received federal EITC, federal and state tax refund amounts, and the state of residence. In addition to these administrative data, the study relies on data from the Household Financial Survey (HFS). The HFS is an annual national household survey administered immediately after tax filing to a random sample of TTFE filers who have consented to participate in the survey. Those who complete the first survey wave are invited to participate in the follow-up survey roughly six months after tax filing. We are thus able to observe each respondent in two time periods throughout the year. Each wave of the HFS contains information about tax filers' demographic and financial characteristics that is not observable through administrative records, which includes the experience of hardships and financial shocks, asset ownership, debt levels, and additional demographic information. Administrative tax records were merged with the HFS data to generate the final dataset for the analysis. While response rates vary marginally year-to-year, $5.7 \%$ of invited TTFE filers responded to the first survey in 2017. Though survey response rates were low, research from prior years generally points to relatively few differences between all TTFE users and those who opt to complete the survey, even as survey respondents do tend to have slightly higher incomes (Grinstein-Weiss et al., 2015). Of those who completed the first survey wave in $2017,34 \%$ took part in the second survey.

\section{Study Sample}

The study sample was limited to EITC-receiving households that participated in both survey waves, received a federal tax refund, completed their taxes before the filing deadline, and had non-missing data on key demographic and financial characteristics. A small share of households ( $0.49 \%$ of the lower-income sample) that received the Child Tax Credit (CTC) but not the EITC was excluded from the sample. We used two sample specifications of EITC recipients for the primary analysis. In the full sample, which is our primary analytical sample throughout the paper, the treatment group consisted of EITC recipients who filed their taxes before February 15th (early filers) and the comparison group included EITC recipients who completed taxes on or after February 15th (non-early filers) (sample $1, n=5,339 ; 3,250$ in 2016 and 2,089 in 2017). Considering that filing taxes on, for example, February 14th may not result in a substantially longer period of waiting for the refund than filing on February 15th, we constructed a separate treatment group restricted to early filers who completed their taxes before February 1st - and thus were most likely to be affected by the new rules-leaving the comparison group unchanged (sample 2, $n=3,896$, 2,372 in 2016 and 1,524 in 2017).

Table 1 presents summary statistics for the full sample of EITC recipients (sample 1) measured at the time of tax filing prior to policy implementation in 2016. Despite limiting the sample to EITC-receiving households, substantial differences are observed between

\footnotetext{
2 The TTFE tax preparation and tax filing software is offered by Intuit, Inc. for free as part of the IRS Free File Alliance to qualifying LMI households (https://freefilealliance.org/).
} 
Table 1 Baseline sample characteristics (full sample), 2016

\begin{tabular}{|c|c|c|c|}
\hline & $\begin{array}{l}\text { Early filers (<Feb 15) } \\
\text { Mean (S.D.) }\end{array}$ & $\begin{array}{l}\text { Late filers (Feb 15+) } \\
\text { Mean (S.D.) }\end{array}$ & $\begin{array}{l}\text { Diff.: } \\
p \text {-values }\end{array}$ \\
\hline Female & 0.578 & 0.543 & 0.043 \\
\hline Age (years) & 37.7 & 38.2 & 0.174 \\
\hline Non-Hispanic White & 0.736 & 0.731 & 0.729 \\
\hline Non-Hispanic Black & 0.108 & 0.073 & 0.001 \\
\hline Non-Hispanic Asian & 0.029 & 0.059 & 0.000 \\
\hline Hispanic & 0.071 & 0.083 & 0.195 \\
\hline Other & 0.057 & 0.054 & 0.748 \\
\hline Married & 0.268 & 0.217 & 0.001 \\
\hline Unmarried with partner & 0.207 & 0.187 & 0.166 \\
\hline Unmarried without partner & 0.525 & 0.596 & 0.000 \\
\hline Non-student & 0.792 & 0.729 & 0.000 \\
\hline Part-time student & 0.060 & 0.073 & 0.132 \\
\hline Full-time student & 0.148 & 0.198 & 0.000 \\
\hline High school degree or less & 0.163 & 0.099 & 0.000 \\
\hline Some college & 0.339 & 0.275 & 0.000 \\
\hline Bachelor's degree & 0.299 & 0.310 & 0.493 \\
\hline Higher than Bachelor's & 0.199 & 0.316 & 0.000 \\
\hline No. of dependents: 0 & 0.403 & 0.646 & 0.000 \\
\hline No. of dependents: 1 & 0.255 & 0.189 & 0.000 \\
\hline No. of dependents: 2 & 0.198 & 0.101 & 0.000 \\
\hline No. of dependents: $3+$ & 0.144 & 0.064 & 0.000 \\
\hline Not employed & 0.228 & 0.249 & 0.166 \\
\hline Employed part-time & 0.281 & 0.388 & 0.000 \\
\hline Employed full-time & 0.491 & 0.363 & 0.000 \\
\hline Lives in owned house/apt & 0.232 & 0.208 & 0.091 \\
\hline Lives in rented house/apt & 0.573 & 0.529 & 0.011 \\
\hline Neither owns nor rents & 0.194 & 0.264 & 0.000 \\
\hline Owns a vehicle & 0.762 & 0.738 & 0.121 \\
\hline Insured & 0.866 & 0.857 & 0.457 \\
\hline Receives TANF or SNAP & 0.372 & 0.255 & 0.000 \\
\hline Unexpected income shock (past $6 \mathrm{mo}$ ) & 0.325 & 0.297 & 0.091 \\
\hline Unexpected expense shock (past 6 mo) & 0.537 & 0.509 & 0.111 \\
\hline Value of liquid assets (median, $\$)^{\mathrm{a}}$ & 400 & 1,075 & $\mathrm{n} / \mathrm{a}$ \\
\hline Amount of unsecured debt (median, $\$)^{\mathrm{a}}$ & 700 & 400 & $\mathrm{n} / \mathrm{a}$ \\
\hline Annual gross income $(\$)$ & $17994(12317)$ & $13648(11261)$ & 0.000 \\
\hline Federal tax refund $(\$)$ & $3,319(2,765)$ & $1,987(2,259)$ & 0.000 \\
\hline State tax refund $(\$)$ & $327(505)$ & $254(467)$ & 0.000 \\
\hline Federal EITC (\$) & $1,895(1,825)$ & $1,119(1,497)$ & 0.000 \\
\hline Federal EITC and CTC (\$) & $2,048(1,840)$ & $1,203(1,541)$ & 0.000 \\
\hline Observations & 1,786 & 1,464 & \\
\hline
\end{tabular}

We used $t$-tests to compare the means of continuous variables and tests of proportions to compare the proportions of binary variables. ${ }^{\text {a}}$ Values are topcoded at the $1 \%$ level 
early and non-early filers in terms of demographic and financial characteristics. For example, compared to late filers, higher proportions of early filers were married (26.8\%), nonstudents $(79.2 \%)$, and employed full-time $(49.1 \%)$, and had lower educational attainment (50.2\% had less than Bachelor's degree) and had dependents in a household (59.7\%). Both groups reported experiencing unexpected income and expense shocks at similar rates six months prior to tax filing. The median value of liquid assets was lower in the treatment than in the comparison group (\$400 and $\$ 1,075$, respectively), whereas the level of unsecured debt was higher ( $\$ 700$ and $\$ 400$, respectively). At the same time, on average, early-filing EITC recipients earned higher annual gross incomes, and received larger tax refunds (federal and state) and larger federal tax credits (EITC and combined EITC and CTC). Overall, the federal tax refund provided a substantial financial windfall—accounting for $18.4 \%$ of the annual gross income among early filers and $14.3 \%$ among non-early EITC filers-while EITC benefits comprised most of the federal tax refund (56-57\%) in both groups.

The differences between the early and non-early filers are consistent with prior evidence (Grinstein-Weiss et al, 2015). Though early EITC filers have higher incomes and receive larger refunds, they report greater incidence of material hardship in the months prior to tax filing. Early filers are also more likely to have dependents and file as heads of household, a proxy for single-parent households which likely face a more pressing set of consumption needs that motivate early filing compared to non-early filers who are more likely to be single. The EITC also offers a considerably higher credit to filers with dependents, which may act as an incentive to file early. The larger reward coupled with the greater needs of the household may help explain the pattern reflected in Fig. 2, which shows that average refund size was largest in the beginning of the filing season and decreased over time. Refund delays resulting from implementation of the PATH Act may thus more negatively affect relatively financially vulnerable households.

\section{Analytical Method}

We use a difference-in-differences (DID) approach as an identification strategy to examine the effects of refund delays due to the PATH Act on household hardship experiences and debt levels. Restricting our sample to EITC recipients, we estimated the following ordinary least squares (OLS) regression model:

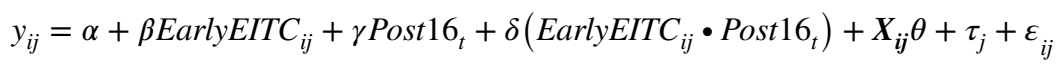

where $y_{i j}$ is an outcome variable for household $i$ in census division $j$; EarlyEITC $i j$ is a dummy variable equal to 1 for an EITC recipient who filed taxes early in the tax season in a given year, and 0 otherwise; Post $16_{t}$ is an indicator variable equal to 1 for the time period following the implementation of the PATH Act provisions, and 0 otherwise; $\boldsymbol{X}_{i j}$ is a vector of demographic and financial characteristics; $\tau_{j}$ captures Census division fixed effects; and $\varepsilon_{i j}$ is an unobserved heteroskedasticity-robust error term. The parameter $\delta$ identifies the average change in outcomes following the implementation of the PATH Act for EITC recipients who filed their taxes early in the tax season relative to EITC recipients who filed their taxes later in the season.

We relied on the time discontinuity in the new rule's dates to distinguish between early EITC filers (the treatment group) and non-early EITC filers (the comparison group). Since the PATH Act mandates that the IRS not issue tax refunds to EITC claimants until at least 
A Average Federal Tax Refund in 2016

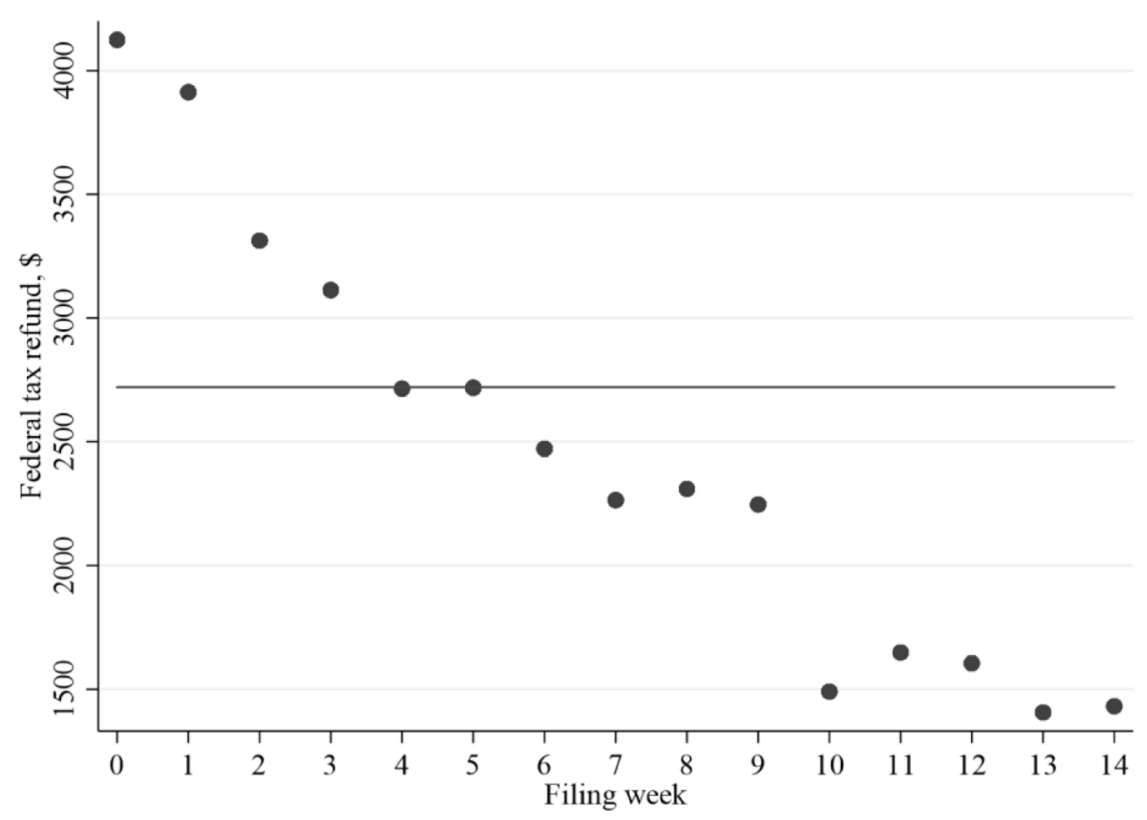

\section{B Average Federal Tax Refund in 2017}

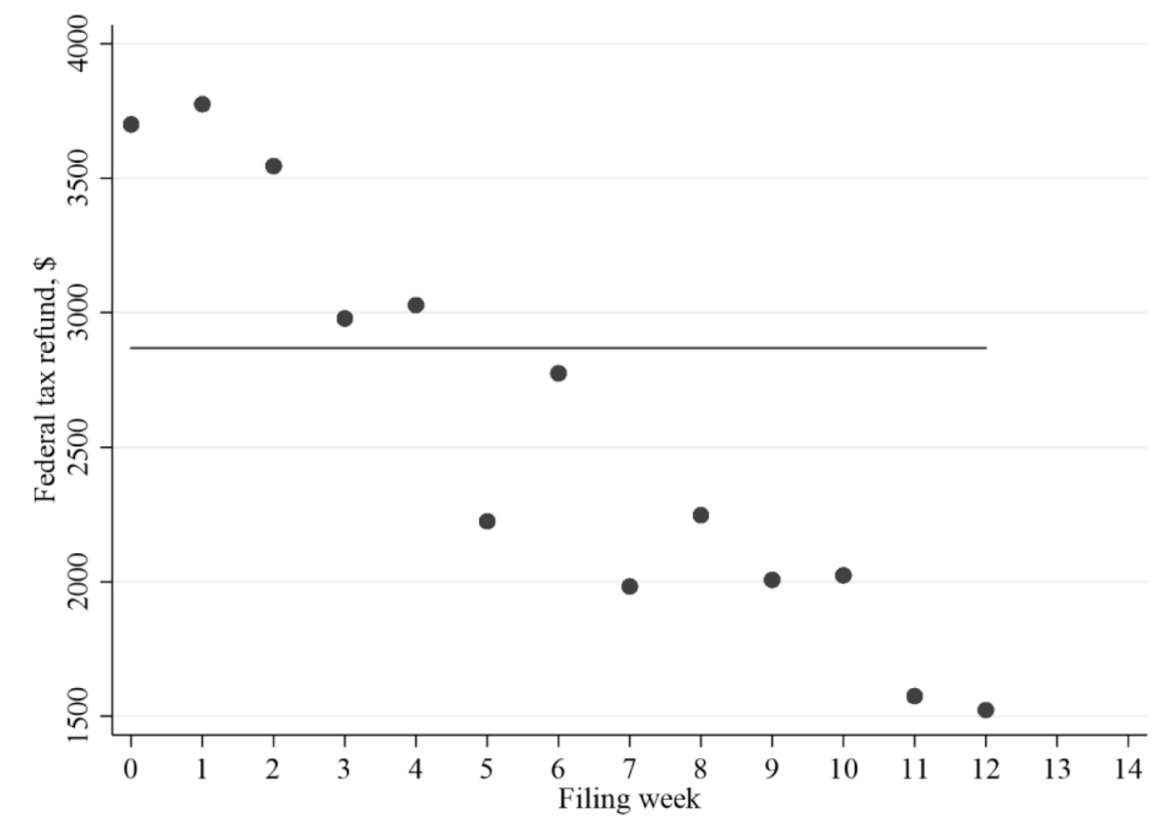

Fig. 2 Average amount of federal tax refund, A 2016 and B 2017. Notes: $n=3,250$ in 2016 and $n=2,089$ in 2017. Horizontal line signifies the average federal tax refund amount for the 2016 tax filing season 
February 15, we used this time discontinuity to construct two samples for the primary analysis. As described above, in the full sample (sample 1), we consider EITC recipients who filed their taxes before February 15 as treated households (early filers) and EITC recipients who completed their taxes on or after February 15 as comparison households (non-early filers). In the restricted sample (sample 2), the treatment group includes early EITC filers who completed their taxes before February 1st and the comparison group is unchanged.

One potential concern with comparing early and non-early EITC filers is that the two groups may be too dissimilar to each other in terms of key demographic and financial characteristics. However, the existence of differences between the two groups is not an issue in itself as long as the two groups would have experienced similar changes in their outcomes in the absence of the policy. We address this potential concern by providing several robustness checks in the "Results" section.

In addition, because the PATH Act did not go into effect until 2017, we consider 2016 as the pre-treatment period and 2017 as the post-treatment period. While we use repeated cross-sectional data and our samples differ across survey years, the TTFE eligibility criteria and the process of sample selection remained stable across the years. We thus expect that the cohorts of households will be similar over years, even if we do not observe the same households. ${ }^{3}$ We provide additional details on the sample composition over time below.

We focused on two types of outcomes measured six months after tax filing: (1) the experience of material and medical hardships, and (2) the incidence of unsecured debt. We use five hardship measures in this study, including a household's reported difficulty in making housing payments, making regular bill payments, affording adequate food, and postponing necessary medical care and prescription drugs due to cost. ${ }^{4}$ Each hardship variable is represented as a dichotomous variable equal to 1 if a household experienced a specific hardship in the 6 months after tax filing, and 0 otherwise. An additional two variables were used to quantify the accumulation of unsecured debt, which includes credit card balances, payday loans, and negative balances in savings and checking accounts. The first unsecured debt variable is a dummy variable indicating whether a household held any unsecured debt 6 months post tax filing. The second unsecured debt variable signifies the intensity of held debt and is measured as a log-transformed unsecured debt balance. ${ }^{5}$ The amount of unsecured debt was also winsorized at the $1 \%$ level-i.e., the highest $1 \%$ of variable values were replaced by the value at the 99th percentile.

The vector of covariates includes a large array of demographic and financial characteristics measured at the time of tax filing, such as respondent's gender, age, age squared, race/ ethnicity, student status, marital status, the number of dependents in a household, highest

\footnotetext{
3 Around 9\% of the analytical sample appeared in both 2016 and 2017. There are several reasons why we do not observe the same households across study years: households may not have used TTFE across the years, they may not have been randomly selected to participate in the survey in both years, they may not have qualified for the EITC in both years, or they may not have completed two survey waves in both years.

4 To measure material hardship, we relied on survey questions administered six months after tax filing that asked respondents whether they "did not pay the full amount of the rent or mortgage because [they] could not afford it," "skipped paying a bill or paid a bill late due to not having enough money," and experienced food insecurity in the past six months. The six-item questionnaire to measure food insecurity was adopted from the U.S. Department of Agriculture (USDA) questionnaire (USDA, 2012) and indicated whether respondents experienced any food insecurity. For medical hardship, respondents were asked whether in the past six months they "needed to see a doctor or go to the hospital but did not go because [they] could not afford it" and "could not fill or postponed filling a prescription for drugs when they were needed because [they] could not afford it".

5 A value of one was added when respondents reported no unsecured debt.
} 
educational attainment, employment status, living arrangement, vehicle ownership, the month and the week of tax filing, the household's participation in the Temporary Assistance for Needy Families (TANF) and SNAP programmes (which provide cash or food assistance to qualifying low-income households), the self-reported value of liquid assets at the time of tax filing (log transformed), the household's annual gross income, and the amount of the federal and state tax refund the household received. While our outcome variables include the amount of unsecured debt held 6 months after tax filing, we also include a control for the self-reported amount of unsecured debt at the time of tax filing, winsorized at the $1 \%$ level. While most of these variables come from self-reported survey data, the values for household income and federal tax refund amount were both measured through administrative tax records. Considering that some states did not have a large number of EITC respondents appearing in our sample, the primary model incorporates Census division rather than state fixed effects.

\section{Key Identifying Assumptions}

The key identifying assumption of DID estimation is that the treatment and comparison groups, on average, would have experienced the same changes in outcomes had the PATH Act provision not been implemented, otherwise known as the parallel trends assumption. There are several reasons why we expect the parallel trends assumption to hold and the DID estimates to be valid in our study.

First, prior research has shown that the vast majority of EITC and CTC recipients-91\% of respondents - were unaware of the upcoming changes in the tax law (Maag et al., 2016). Similarly, evidence from California demonstrates that even several years after the state adopted a relatively generous state EITC programme, less than one half of qualifying individuals claimed the credit, prompting the government to increase funding to raise awareness of the state credits (Legislative Analyst's Office, 2018). Both of these studies suggest that households are generally not aware of the changes in the tax reforms-even if these changes can have significant direct financial implications for them. This general lack of knowledge about the new tax refund legislation suggests that early and non-early EITC recipients were unlikely to have adjusted their financial and tax filing behaviours in anticipation of the PATH Act rules.

A further inspection of basic characteristics of early and non-early filers across the 2016 and 2017 years in Table 2 also shows support for the parallel trends assumption. While there are some differences in key demographic and financial characteristics in these groups between the two years, most differences were statistically or economically insignificant. This generally suggests that the composition of each group stayed largely unchanged between 2016 and 2017. It is important to note that educational attainment levels-which could potentially be a proxy for greater familiarity about upcoming changes in the tax code- did not differ across the years among early filers. Although the differences in educational attainment were statistically significant between the years for later filers (the 2017 sample had a somewhat higher percentage of those with a Bachelor's degree and a somewhat lower percentage of those with some college education), it does not appear that this was due to the changes in the sample composition among early filers. In other words, it is unlikely that the slightly higher proportion of individuals with a Bachelor's degree in 2017 among late-filing EITC recipients occurred because early filers with more education and, potentially, more familiarity with the tax code decided to delay their tax filing dates between 2016 and 2017 . 


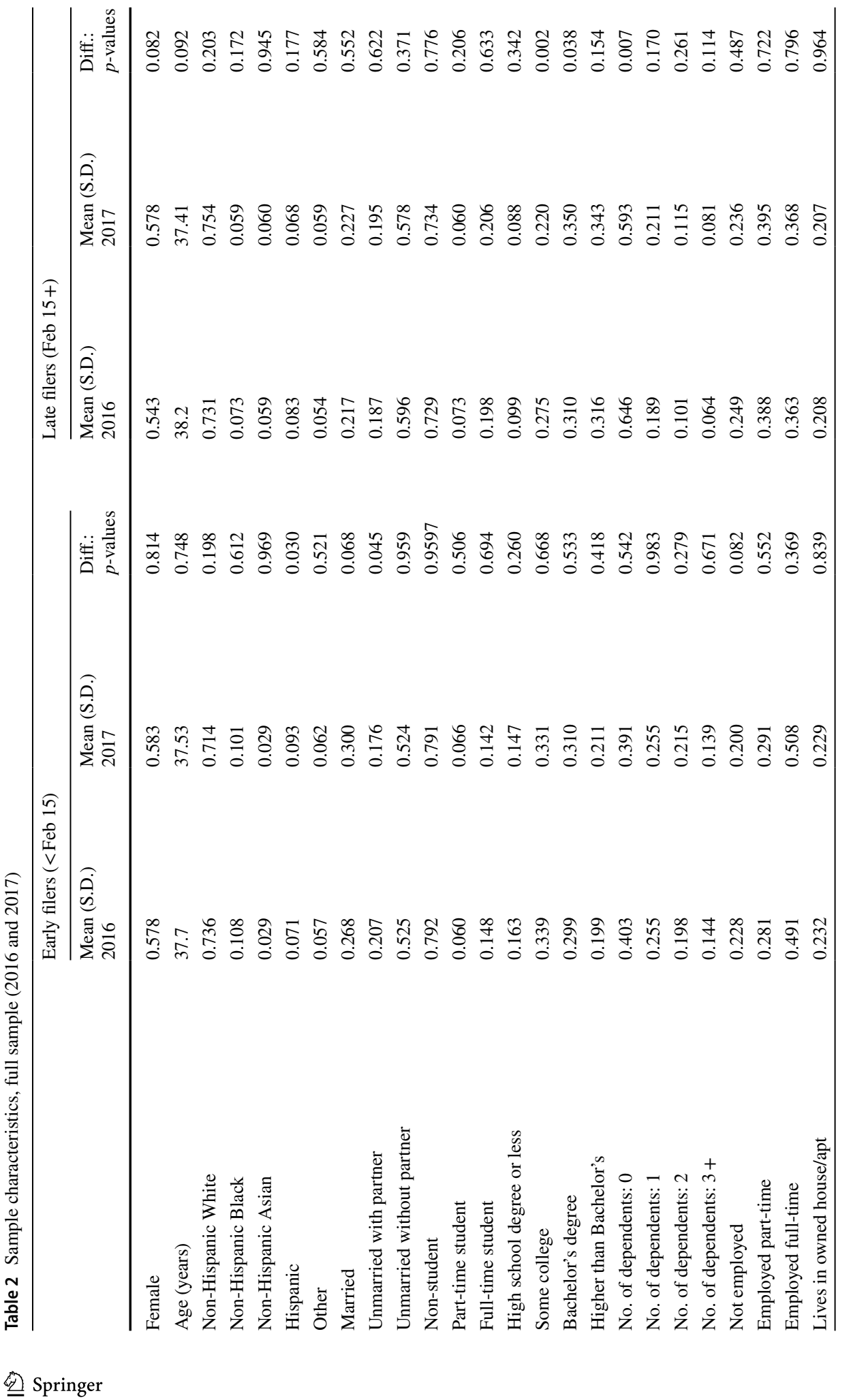




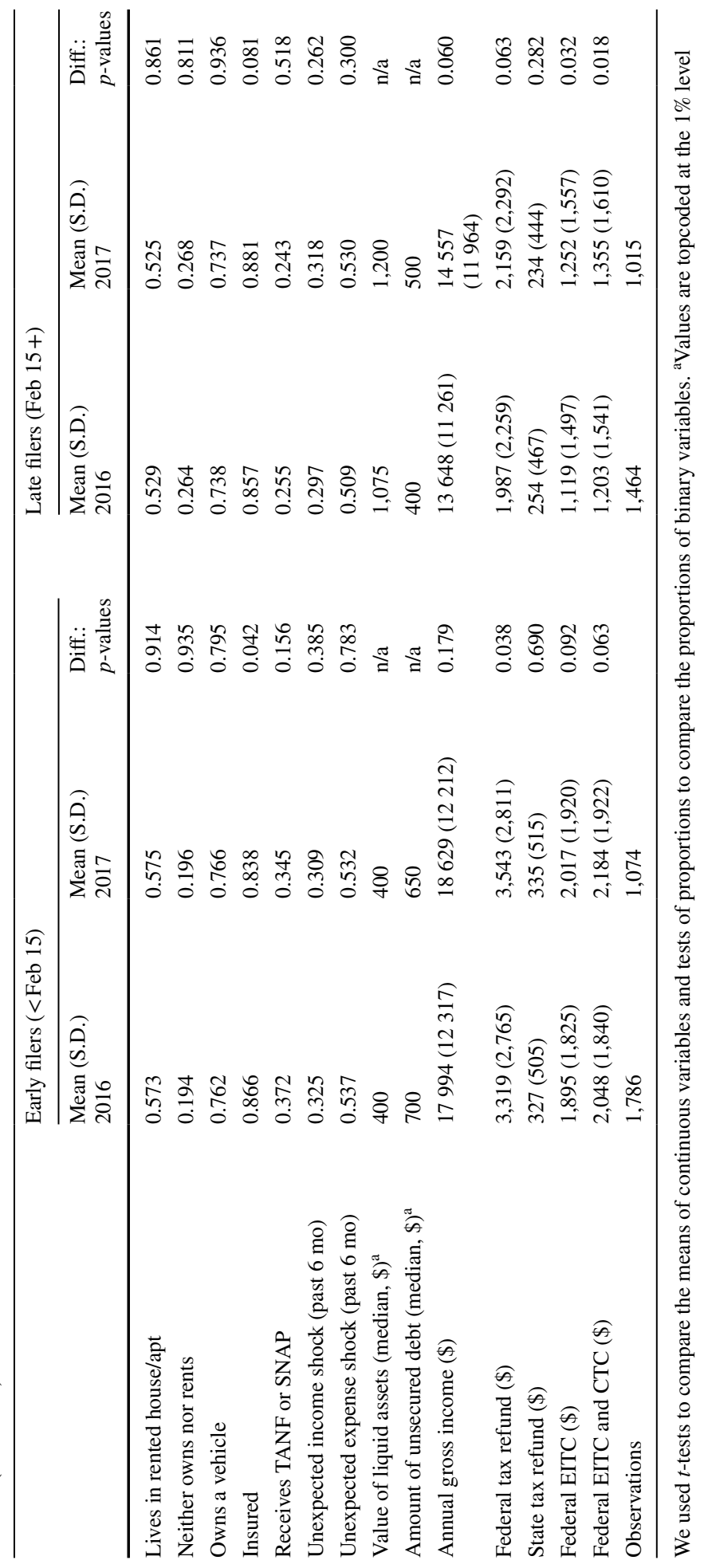


Fig. 3 Tax filing in A 2016 and B 2017. Panel C Proportion of tax season completed in 2016 and 2017. Notes: $n=3,250$ in 2016 and $n=2,089$ in 2017. Vertical line in panels $\mathbf{A}$ and $\mathbf{B}$ corresponds to February 15

Second, the new legislation was put into effect in response to broad concerns around tax errors and tax fraud, and was not targeted at specific groups of EITC claimants. Since the implementation of the PATH Act was not linked to household characteristics or financial circumstances, the two groups of early and non-early filers were unlikely to face any unequal pre-treatment changes in outcomes that would subsequently influence their exposure to treatment. Third, to our knowledge, there were no simultaneous changes in other federal policies and programmes that targeted early EITC filers but not late EITC filers. Any policy change influencing all EITC recipients simultaneously would get absorbed by inclusion of controls for the time trend. Fourth, the date of February 15 appears arbitrary and we expect that EITC recipients just below and just above this date discontinuity would not differ substantially from each other. As a robustness check, we used a number of alternative specifications to test the sensitivity of our findings to different sample classifications.

Finally, it is possible that there existed some state policies that differentially targeted early and non-early EITC filers (though it is unlikely that they would have relied on February 15 as a cut-off to separate early and non-early filers). Controlling for the state tax refund in the main model and including state fixed effects and Census division-year interaction terms in the robustness section helps alleviate these concerns, and helps control for any variation associated with the value of different state tax credits, such as state EITCs. For these reasons, we expect that the parallel trends assumption has been met and our analysis will generate an unbiased estimation of the causal effect of the PATH Act rules on household financial outcomes.

\section{Results}

\section{Patterns of Tax Filing over Time (2016 and 2017)}

We begin by illustrating tax filing behaviours over time in 2016 and 2017 for the full sample of EITC recipients. In panels A and B in Fig. 3, the $y$-axis corresponds to the proportion of EITC recipients filing their taxes on each day of the tax filing season, and the $x$-axis signifies the date of tax filing. Both panels show that the majority of EITC households filed returns in the first four weeks of the tax filing season (56.4\% in 2016 and $57.7 \%$ in 2017) and a notable fraction of tax filers completed taxes in the last week of the tax season $(10.2 \%$ in 2016 and 2017). The remaining households filed taxes during the intervening weeks.

Considering that the tax filing season dates differed across the years- the filing season ran between January 19 and April 18 in 2016 and between January 23 and April 18 in 2017-we used a common unit of measurement to make a robust comparison of tax filing patterns between the years. In panel $\mathrm{C}$, the $y$-axis is defined as above, while the $x$-axis denotes the number of days since the beginning of the tax filing season as the proportion of the entire filing season (e.g., 10\% into the tax filing season). Two important insights emerge from the comparison of tax filing trends in panel C. First, tax filing behaviours appeared remarkably similar across the years: $51.4 \%$ of EITC filers completed their taxes before February 15 in 2017, and 52.1\% of EITC recipients filed taxes during the equivalent time period in 2016. This pattern suggests that, on average, EITC filers continued to file similarly across the years and did not adjust the timing of tax filing in substantial ways when the PATH Act went into effect. Second, a non-negligible proportion of EITC 
A Tax Filing in 2016

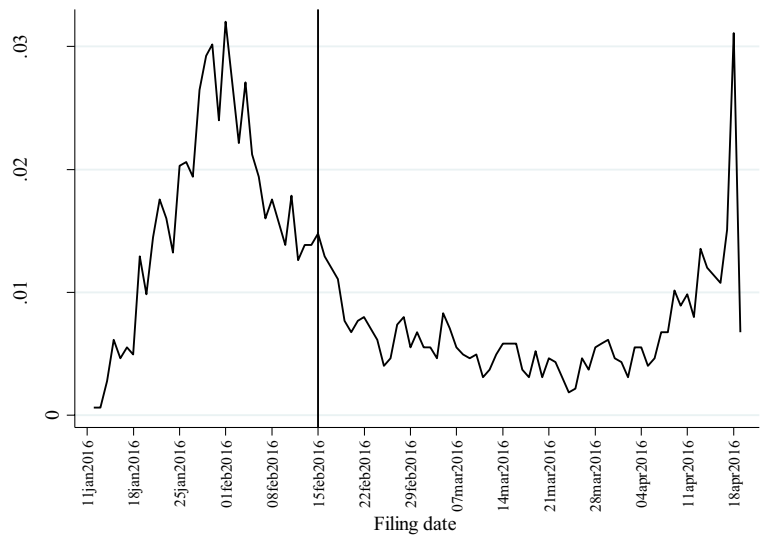

B Tax Filing in 2017

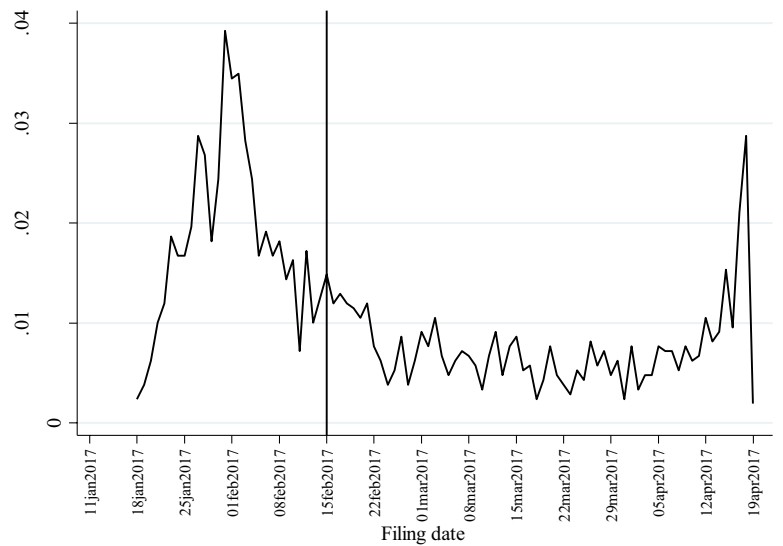

C Proportion of Tax Season Completed in 2016 and 2017

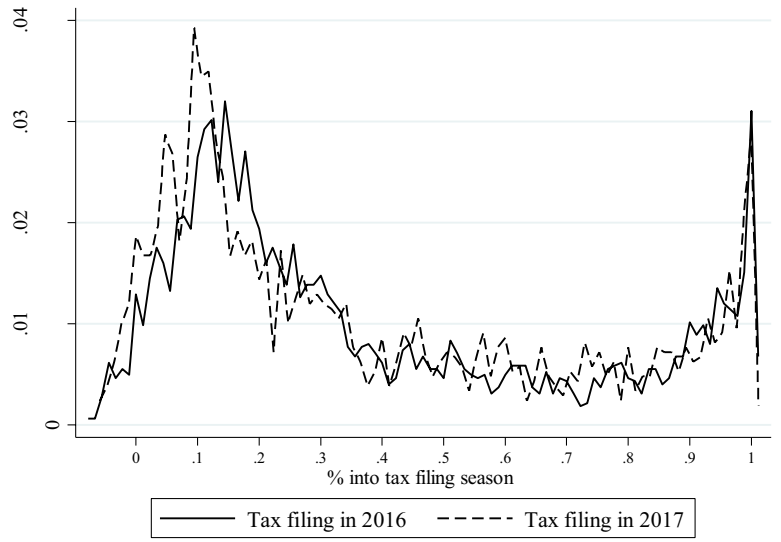


recipients filed their tax returns even before the start of the tax filing season. When combined with the fact that the majority of EITC recipients filed returns in the first several weeks of the tax filing season, this finding demonstrates that a considerable share of filers filed their taxes very early in the tax season and were therefore subject to multiple-week delays in receiving tax refunds.

\section{Difference-in-Differences Estimates: Overall Effects}

Table 3 presents the DID estimates of the effects of the delayed refunds on households' experience of material hardships, medical hardships, and unsecured debt. Panel A includes the full, least restrictive sample of tax filers (sample 1) and panel B restricts the group of early tax filers to those who filed before February 1 and were most likely to be affected by the policy (sample 2). The coefficient of interest, $\delta$, describes the average changes in outcomes in the treatment group relative to the comparison group, after the PATH Act provisions took effect in 2017. The table presents estimates of time-invariant differences in baseline outcomes between early and non-early filers $(\beta)$ and the time trend common to both groups $(\gamma)$. Each regression includes the full set of control variables. The full results from these regression models are included in the Appendix (Tables 7 and 8). Statistical significance is interpreted at the 0.05 level.

The key finding in Table 3 is that we consistently observe a positive coefficient on the experience of food insecurity six months post tax filing (column 5). Specifically, results from the full sample in panel A indicate that after the policy change, the likelihood of experiencing food insecurity was 6.9 percentage points higher among early filers relative to non-early filers. After limiting the treatment group to the very early filers in panel B, the coefficient on the interaction term increased to 9.6 percentage points. The larger coefficient magnitude is to be expected considering that the treatment group in panel B consists of very early filers who would be expected to experience disproportionately longer and therefore more consequential refund delays. Taken together, these findings demonstrate that EITC recipients who faced delays in receiving their tax refund due to the PATH Act faced increased rates of food insecurity in comparison with EITC recipients who did not face delayed refund payments.

Exploring the coefficients beyond the interaction terms in column 5 provides a more comprehensive picture of the experience of food insecurity following the tax reform. The coefficient on the early filer indicator suggests that there were no significant differences in average levels of food insecurity at baseline between the treatment and comparison groups. The coefficient on the time dummy points to a statistically significant downward trend in the rate of food insecurity in the comparison group over time. This pattern is observed for both samples. Our results therefore seem to indicate that while households unaffected by the refund delay saw a reduction in the experience of food insecurity over time, those that experienced delays in receiving their federal tax refunds did not experience the same secular improvements in food insecurity between 2016 and $2017 .{ }^{6}$ Finally, we did not observe statistically significant effects of the PATH Act for other hardships and unsecured debt outcomes (Table 3).

\footnotetext{
${ }^{6}$ It is worth noting that similar-though more muted-trends in the comparison group are observed even when regressions do not include covariate variables.
} 


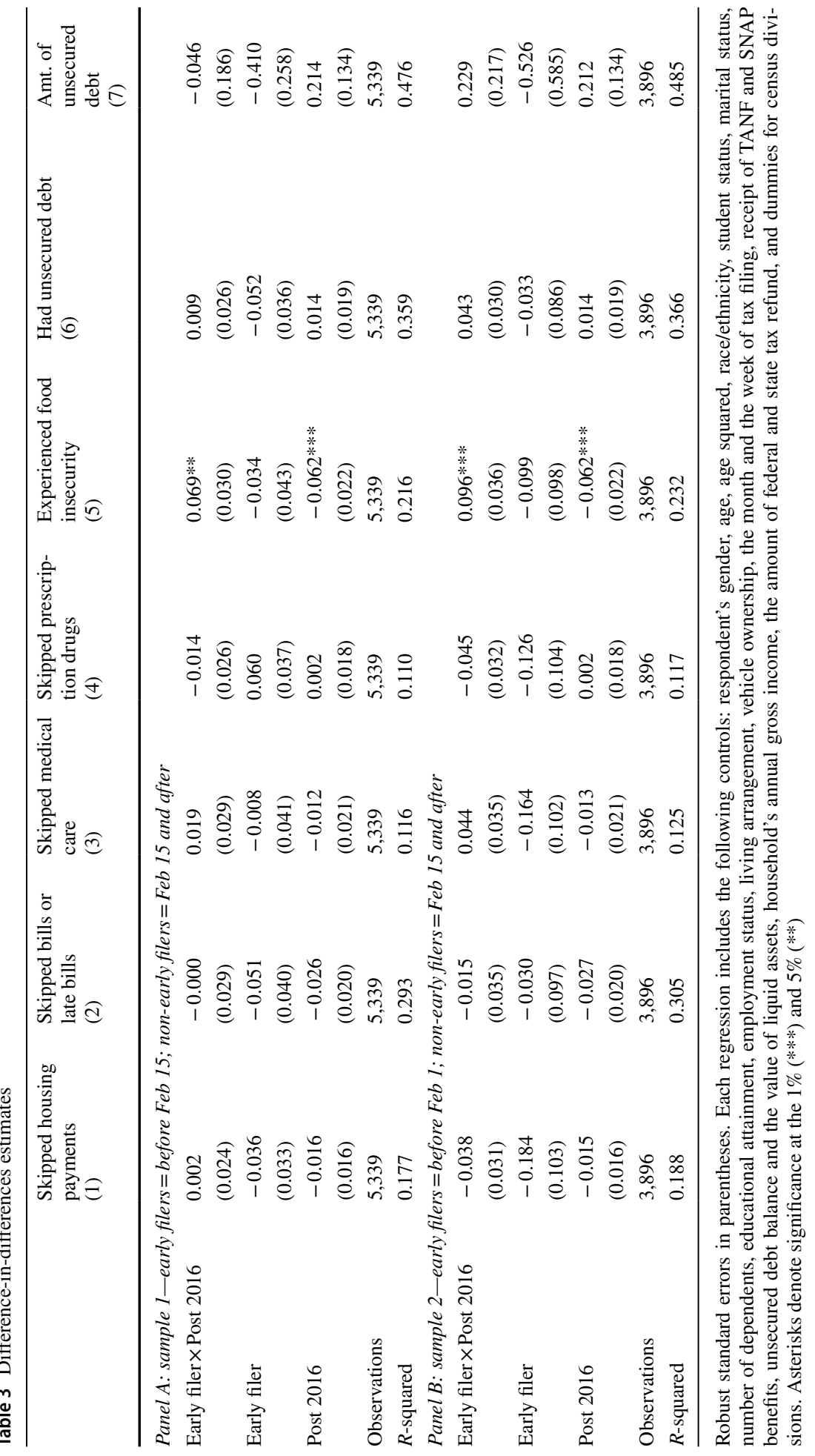




\section{Difference-in-Differences Estimates: Heterogeneous Effects by Refund Amount}

While Table 3 reports the average effects of the PATH Act on hardship and debt outcomes, delays in receiving the tax refund may not have affected all households equally. Some households qualified for much lower credit amounts than others, and as such may have experienced less of an impact from a delayed refund. For example, single filers claiming no dependents could receive a maximum of $\$ 519$ from the EITC, while those claiming 3 or more dependents could receive a maximum of $\$ 6,431$. In Table 4 , we compare the estimated impact of the refund delay on households who received a refund at or below the median amount of $\$ 1,493$ with those who received above the median amount. Our findings based on the full sample of EITC households (sample 1) illustrate some heterogeneity in PATH Act impacts, as the magnitude of the negative coefficient on food insecurity was larger for EITC recipients who received a federal tax refund above the median amount ( $\$ 1,493$ or more). This provides some evidence that those who faced delays in receiving larger payments were more exposed to hardship as a result of those delays, though both estimates lacked precision.

\section{Patterns in Tax Filing Dates Between 2016 and 2018}

While households experienced adverse effects of the PATH Act in the short run, it is unclear whether the effects would persist in the future. In particular, EITC recipients in 2018 may have learned about the tax reform from the prior year-i.e., that filing their taxes earlier would not result in receiving earlier tax returns - and adjusted their tax filing behaviours by postponing the tax filing date by a few weeks to avoid an extra wait for tax returns. To examine the degree to which households may be adjusting their tax preparation and filing behaviour in response to the delay, we replicated Fig. 3 by plotting the patterns of tax filing over time for EITC recipients between 2016 and 2018. The two graphs in Fig. 4 show the proportion of EITC filers who filed in a given day during the tax season. Panel A shows the trend in filing over the course of the tax season using the actual date in 2018, while panel B shows the trend in filing based on the relative dates (e.g., 10\% into the tax filing season) between 2016 and 2018.

Panel A in Fig. 4 shows that the earliest date at which EITC recipients filed taxes in 2018 was January 17th, which is comparable to the earliest tax preparation dates in 2016 and 2017 (January 12th and January 16th, respectively, as shown in Fig. 3). That is, tax filing dates were relatively similar across the years despite the greater differences in tax season dates between 2016 and $2018 .^{7}$ The similarity in terms of tax filing dates indicates that early EITC filers appear to be relatively insensitive to the dates of the actual tax season, and their decisions on when to file tax returns may be guided by factors other than the official tax season dates. For example, EITC recipients may decide when to complete their tax

\footnotetext{
7 While throughout the paper we refer to tax filing, this process consists of two parts: tax preparation and submission of tax returns. In most cases where filers use electronic tax filing software, the two actions happen close to each other-The filer prepares their taxes and then immediately files them using the software. However, in some cases, tax preparation dates may differ from tax return submission dates: Tax preparation dates refer to the period when software companies start accepting tax returns, while tax return submission dates refer to the time when tax returns are submitted to the IRS. Although tax filers can prepare their tax refunds through tax filing companies ahead of the official tax season, their tax returns will get transferred to the IRS only at the start of the tax filing season.
} 


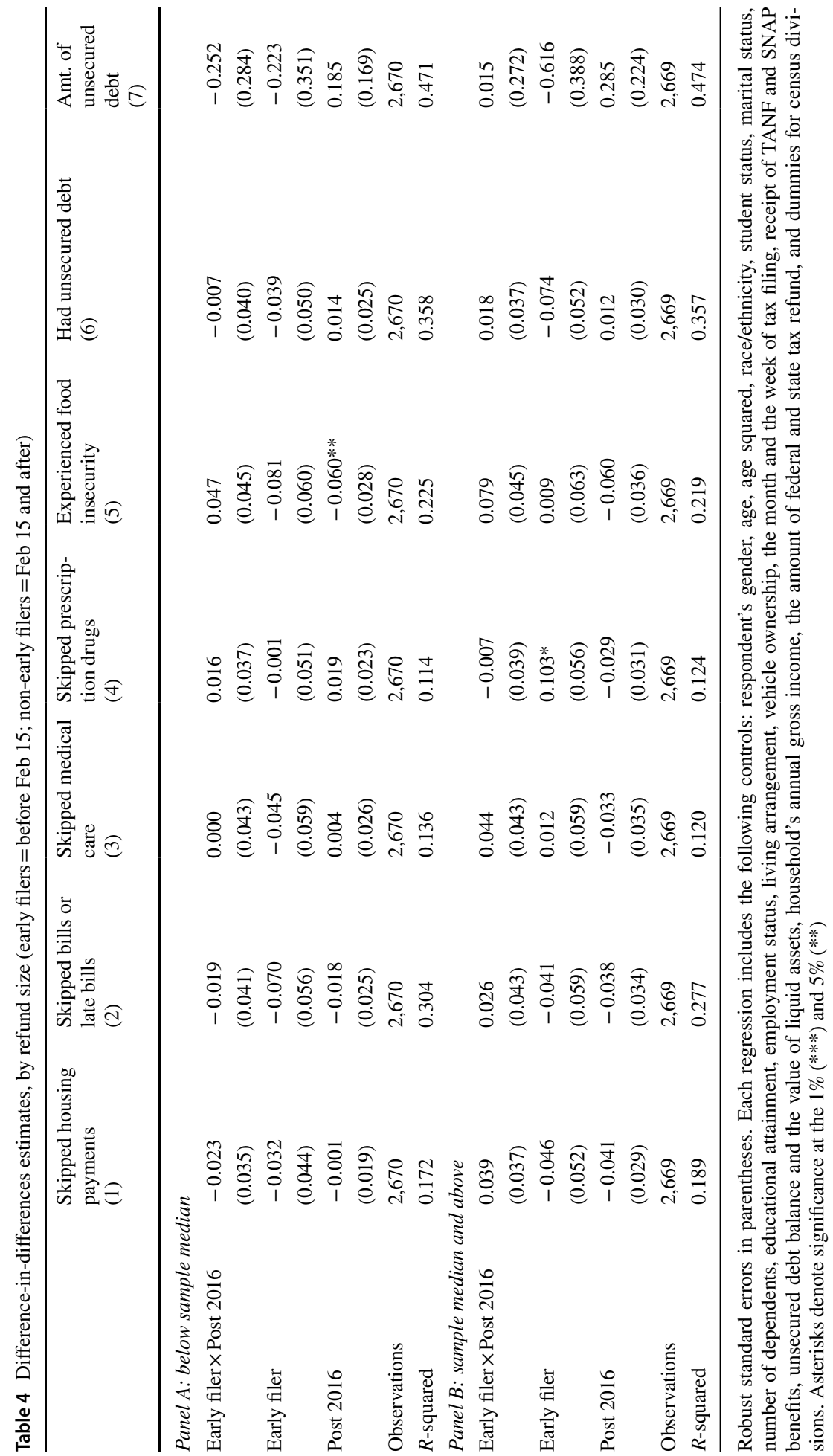




\section{A Tax Filing in 2018}

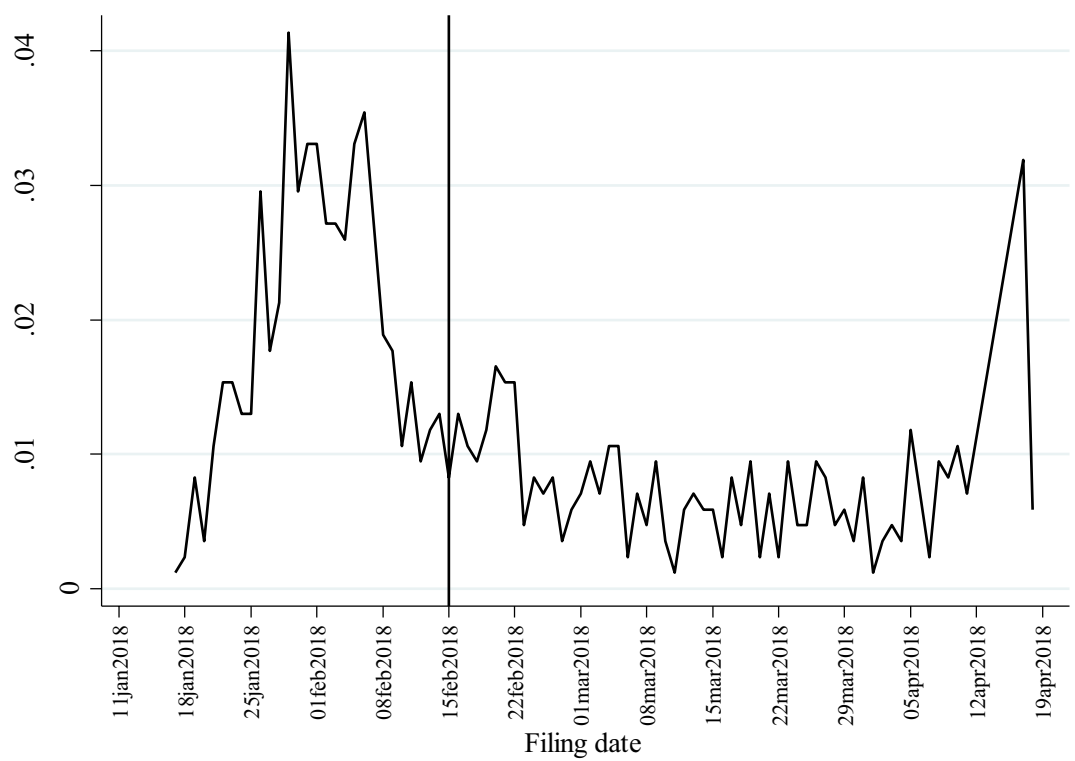

\section{B Proportion of Tax Season Completed in 2016-2018}

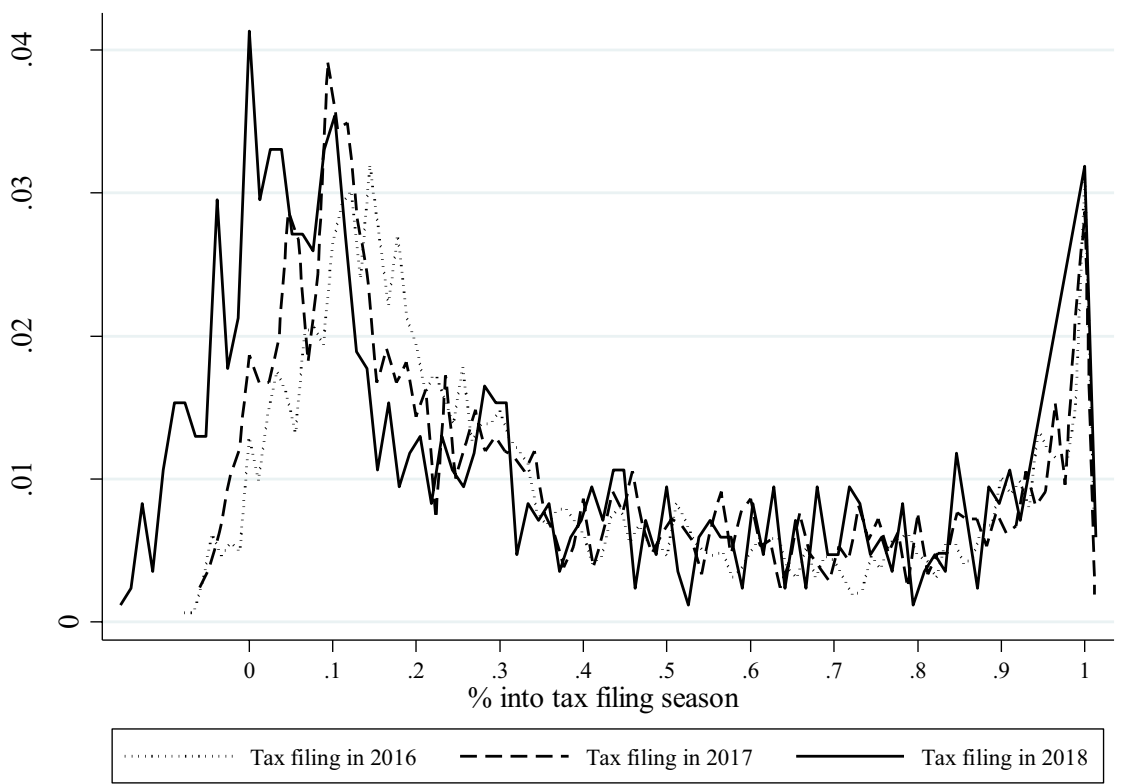

Fig. 4 Panel A Tax filing in 2018. Panel B Proportion of tax season completed in 2016-2018. Notes: $n=3,250$ in 2016; $n=2,089$ in 2017; and $n=847$ in 2018. Vertical line in panel A corresponds to February 15 
returns based on the dates when tax filing software companies and tax professionals. Panel B in Fig. 4 reveals that one year after the introduction of the PATH Act, tax filers have generally not delayed the filing of their tax returns and the majority of EITC filers continued to be subject to the PATH Act delays in 2018. The EITC filers in our sample appeared insensitive to the start of the filing season on January 29th-which came relatively late in comparison to prior years-and a non-negligible proportion of filers completed their refunds before the tax season. A similar conclusion can be drawn when limiting the sample to EITC households that appeared in both 2017 and 2018: The median tax filing date was February 14th in 2017 and February 8th in 2018 for these households. The likely incidence of delays in receiving the federal tax refund, therefore, was high even one year after the tax reform.

Taken together, the two panels in Fig. 4 suggest that the timing of tax filing appeared relatively insensitive to the actual tax season even after the introduction of the PATH Act, and the majority of EITC filers continued to be subject to the PATH Act rules. While we cannot provide the exact mechanisms underlying these tax filing patterns, one interpretation of these patterns is that tax filers remained unaware of the exact PATH Act rules even one year after the introduction of the regulation.

\section{Robustness Checks}

In this section, we examine the robustness of our main findings to the specification of alternative comparison groups, the incorporation of additional years of data, and the inclusion of additional controls. The analysis so far has contrasted the average outcomes for early and non-early tax filers that received the EITC. While treated households appeared relatively dissimilar to comparison households (Table 1), these baseline differences will not invalidate the identification strategy if both groups would have experienced identical average changes in outcomes in the absence of the policy, and if EITC filers in 2016 did not systematically adjust their filing behaviours in 2017. We construct several alternative model specifications to test this assumption. First, we re-estimated our models using several alternative treatment and comparison groups. The first model (Table 5, panel A) mimics the analysis reported in panel A of Table 3, except it includes non-EITC filers completing their taxes late in the season (on or after February 15th) as a "fake" treatment group. That is, the model compares the trends between non-early EITC filers and non-early non-EITC filers. An inclusion of a fake treatment group that we know was not subject to the new policy helps assess the parallel trends assumption and validity of the DID estimates (Gertler et al., 2016). The second model (Table 5, panel B) focuses on EITC filers, but alters the definition of early and late filers. The sample includes early EITC filers who completed their taxes between February 1st and February 14th, while a more limited group of non-early filers consists of those who filed between February 15th and February 28th or 29th. For comparison, the main analysis defines early filers in 2016 as those who filed between January 18th and February 14th and later filers as those who filed between February 15th and April 18th. This more restrictive sample consists of households that were likely more similar to each other in terms of demographic and financial characteristics, and who likely received their refunds around the same time, meaning we should observe fewer differences between these two groups if the assumptions of the DID are valid. As expected, in both panels A and $\mathrm{B}$ in Table 5, the coefficients on the experience of food insecurity were not significant at the 0.05 level, indicating no significant differences between the alternative groups. 


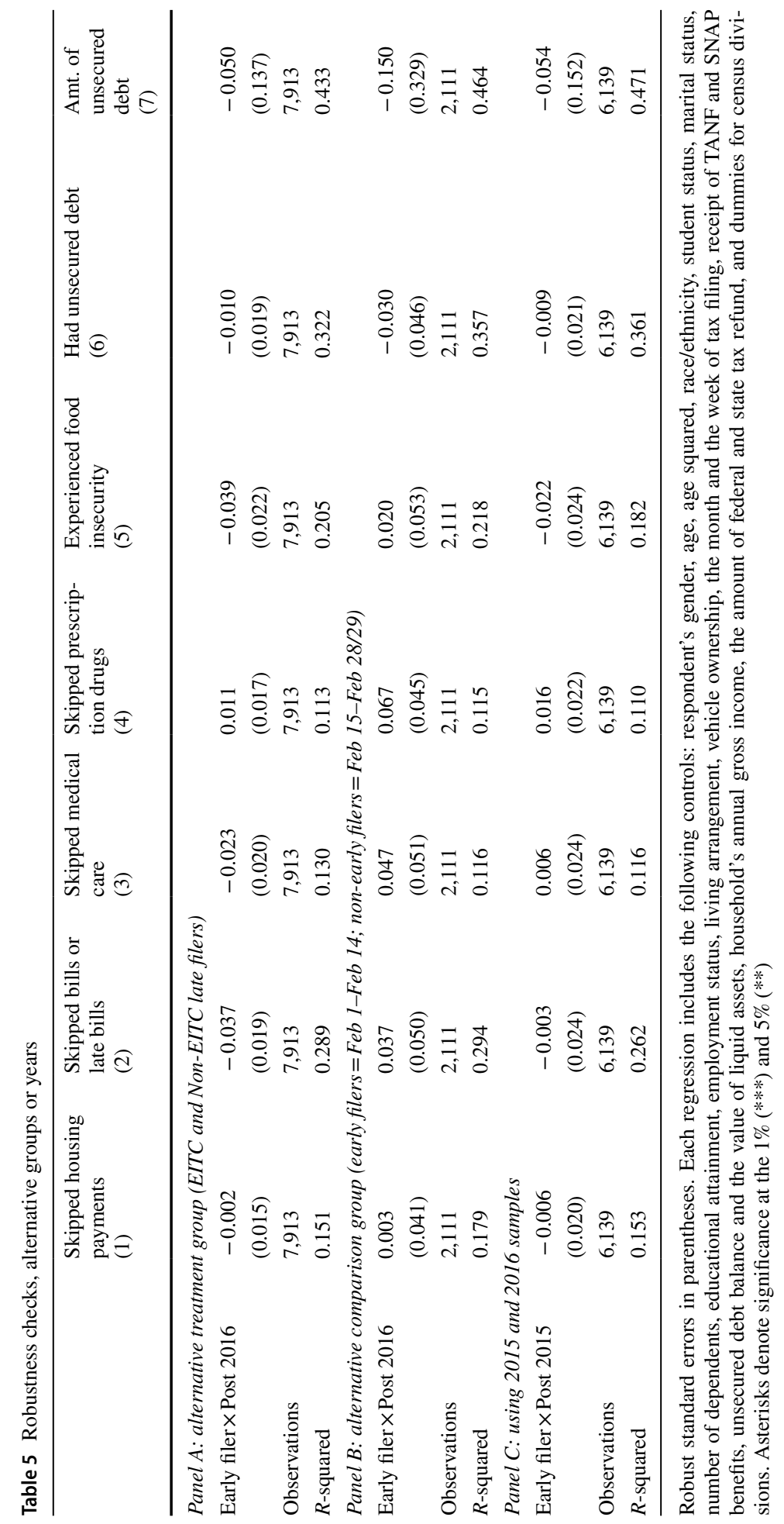


In the second set of robustness tests (Table 5, panel C), we performed a placebo test by using data from multiple pre-treatment years, which further allows us to empirically test the validity of the parallel trends assumption (Gertler et al., 2016). Using data from 2015 and 2016, we re-estimated the main DID analysis to compare early and non-early EITC filers across the years prior to the introduction of PATH Act rules. ${ }^{8}$ We report results for the full sample, finding that coefficients in each model using data from pre-treatment years were statistically insignificant at the 0.05 level, increasing our confidence that the previously estimated relative differences in hardships between the treatment and comparison households can be attributed to the changes in the tax law.

In the final set of analyses (Table 6), we explored how adding state fixed effects to account for time-invariant state-specific factors and interacting census division (panel A) and a year to account for time-varying regional changes affected our results (panel B). The positive coefficient on the likelihood of experiencing food insecurity was observed in each of these specifications, further highlighting the robustness of this result.

\section{Discussion}

This study uses a unique dataset combining administrative tax and longitudinal survey data to study the impacts of the recently implemented PATH Act—which delays issuance of federal income tax refunds for EITC and ACTC filers until at least February 15-on household hardship and unsecured debt outcomes in the 6 months following tax filing. We observe that EITC recipients do not adjust their tax filing behaviour in response to the delay in receiving their tax refund; the tax filing patterns of EITC recipients are similar in 2016 and 2017, years that immediately precede and follow the implementation of the PATH Act rules. Second, our difference-in-differences analysis reveals that the incidence of reported food insecurity 6 months after tax filing increased among early EITC filers relative to non-early EITC filers after the implementation of the PATH Act. This finding is consistently observed across different analytic samples and model specifications. Additional analyses suggest that these negative effects are larger for households who stood to receive larger refunds and thereby had more income deferred as a result of the delay.

We draw several conclusions from our analysis. First, the sensitivity of household food insecurity to the refund delay indicates that changes to food consumption may be one of the first and primary strategies households follow when faced with a liquidity shock. This finding is not surprising given that households can choose from an array of options in adjusting their food consumption, including purchasing less expensive food, reducing the size of meals, or skipping meals. This is consistent with prior evidence showing that food consumption is very sensitive to income fluctuations, and that low-income families respond to food shortages by forgoing desired food items, cutting meal portions, and reducing the frequency of meals to alleviate the experience of food hardship (Heflin et al., 2011). The sensitivity of food security to changes in liquidity speaks to the possibility that lower-income households may prefer to adjust their food consumption rather than skip other necessities like housing or utility payments, as the potential consequences of forgoing those payments may be more severe (e.g., eviction, utility shut-offs). Furthermore, lower-income

\footnotetext{
${ }^{8}$ The analysis using 2015 and 2016 years relies on the simplified financial insecurity measure, which includes a binary yes/no measure of food insecurity rather than the USDA-based food insecurity scale.
} 


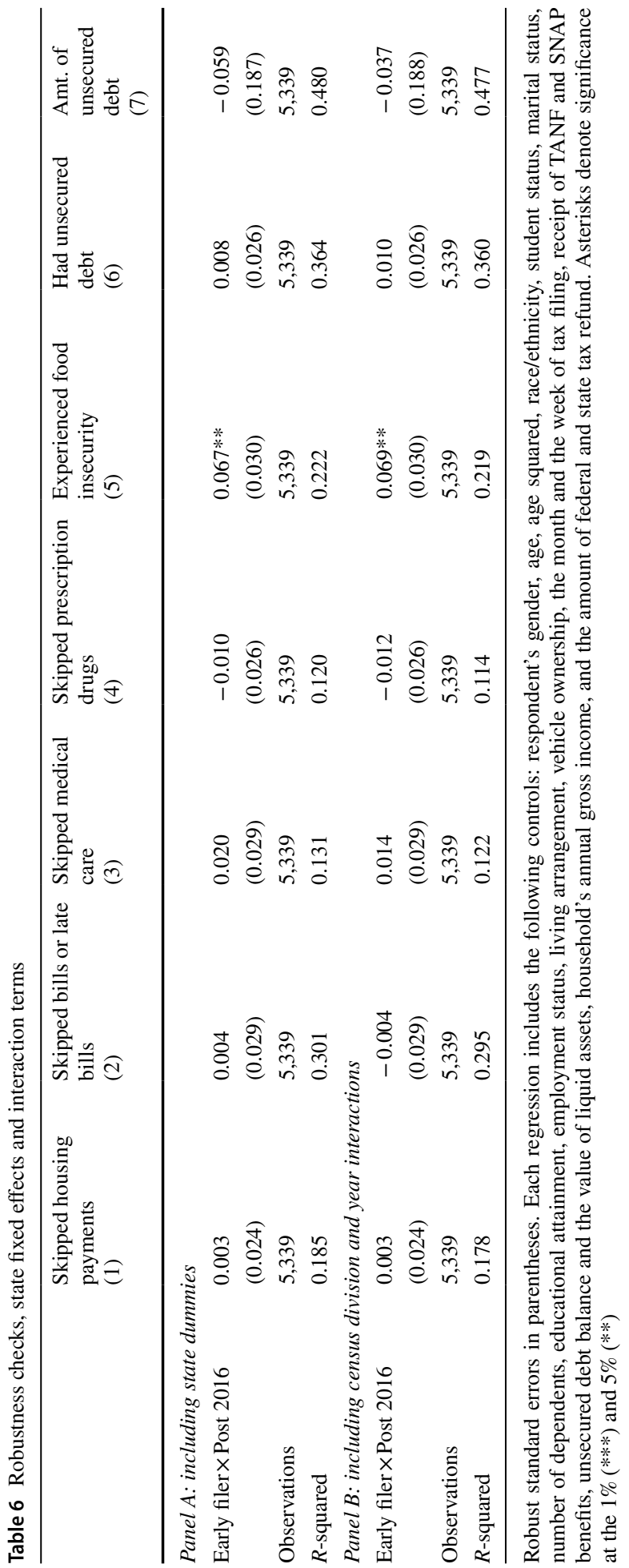


households may be better able to absorb the impact of refund delays with respect to bill payments by shifting those payments to the future (e.g., paying the minimum on credit cards or falling slightly behind on a rent payment) with relatively few consequences, but this is not true for food consumption-a skipped meal remains a skipped meal.

Second, this research provides evidence that even relatively short-though likely unexpected-delays in tax refunds caused by the PATH Act may partially offset the positive impacts on food security attributed to the EITC and other federal programmes, such as SNAP (McGranahan \& Schanzenbach, 2013; Ratcliffe et al., 2011). Considering these adverse effects of the PATH Act provision on early filers, policymakers should consider the possibility of developing alternative, more effective methods to detect or prevent errors in EITC claims. Since most EITC errors are related to the complexity of tax rules rather than fraud (Greenstein et al., 2019), one way to reduce the rate and amount of overpayments would be to expand EITC recipients' access to free resources that help ensure accurate tax filing. For example, the IRS found that over two-thirds of EITC claimants used a paid third-party tax preparer while only $3 \%$ used preparers affiliated with IRS-sponsored volunteer tax preparation sites (Leibel, 2014). This is likely leading to increased EITC filing errors, as these third-party preparers overclaim EITC dollars by 33 to $40 \%$, while IRSsponsored preparers have an EITC dollar overclaim rate of only 11 to $13 \%$. Taking steps to ensure that paid preparers are appropriately trained and certified, or increasing funding for and awareness of these IRS-sponsored free tax preparation options may provide an effective tool against erroneous EITC claims that does not impose delays in tax refund receipt and expose households to financial risk. Another way to enforce greater compliance with EITC rules and counteract overpayments would be by securing more adequate resources to administer the delivery of tax credits. As the budget for IRS enforcement activities has been decreasing over time (Greenstein et al., 2019), an increase in enforcement funding and adoption of more effective auditing strategies may increase tax compliance, reduce tax fraud and errors, and increase the amount of collected taxes across the income spectrum without putting an additional financial strain on low-income households.

Relatedly, these results may also speak to potential consequences of administering so much of the US social safety net through the tax system. That is, if a refund delay of two weeks is leading to increased food insecurity, then it is possible that requiring households to wait several months before receiving their tax refund (i.e., the period between the end of the tax year and the date of actually receiving their refund payment) has similar consequences. By contrast, structuring tax credits to be paid out more periodically, as has been proposed elsewhere (Bellisle \& Marzahl, 2015; Holt, 2015), may help recipients better manage their budgets and avoid the income shortfalls that may be associated with less regular payments. Indeed, the recently expanded Child Tax Credit took this approach, as recipients could receive monthly payments of a portion of this credit between July and December, 2021. Interestingly, while our findings indicate that a delay in refund payments led to increased food insecurity, preliminary research on the periodic Child Tax Credit payments indicates that the first few payments deceased food insecurity security among (Perez-Lopez, 2021; Roll et al., 2021), which further validates the link between tax credits and food security.

Finally, if the PATH Act rules persist into the future, it will be important to provide lower-income households with adequate informational resources to counteract the negative effects of refund delays. Policymakers and practitioners will have to be actively engaged in efforts to raise awareness of PATH Act provisions among lower-income households prior to the tax season. Maag et al. (2016) show that over nine-tenths of early filers who received the EITC did not know about the potential for refund delays in advance of the PATH Act. Efforts to raise lower-income tax filer's awareness of potential delays could take place 
through companies participating in the IRS' Free File Alliance, community-based organizations, faith communities, companies sponsoring Volunteer Income Tax Assistance (VITA) sites, and local departments of social services. Employers could also include brief informational messages about PATH Act refund delays with their annual communication about W2 form availability prior to tax season.

While the short-term effects of the PATH Act on household consumption behaviours and outcomes have been documented by this study and Aladangady et al. (2018), the longterm effects of the change on household behaviours and outcomes are unknown. Though our data show that lower-income tax filers did not appear to respond to the delay in refund receipt by delaying their date of tax filing in the years after the PATH Act, over the longterm households could adjust to the delay in a number of ways, including shifting their consumption forward in time, taking on additional debt that they will pay off with the refund, borrowing from friends and family, drawing down savings, or reducing expenses over the prior year. The extent to which they do so should be a subject for future research, although in the near-term these relationships may be confounded by high rates of job loss and financial hardship during the COVID-19 pandemic (Despard et al., 2020), as well as policymakers' decision to delay tax filing deadlines in response to the pandemic.

This study contributes to the literature in several ways. First, to our knowledge, only a single other study has investigated the impact of the PATH Act for low-income households, finding that refund delays affected spending on essential purchases, such as groceries and non-durable goods (Aladangady et al., 2018). Besides the unique contribution to the scarce literature on the recent PATH Act reform and on the timing of refund payments in general, an additional advantage of our study is that we use administrative individual-level tax data to precisely estimate which households receive the EITC, the amount of federal tax refund they receive, and the exact date of tax filing. Second, this paper contributes to the broader literature examining the relationship between transitory income shocks and household consumption behaviours and hardships. Our findings are consistent with other studies showing that the experience of shocks is associated with increased food hardship (Leete \& Bania, 2010; McKernan et al., 2009) and that a temporary withholding of paychecks can result in lower consumption (Baker \& Yannelis, 2017; Gelman et al., 2018). In comparison to these studies, our research focuses explicitly on the lower-income population and, unlike other studies exploring experiences of hardship (Leete \& Bania, 2010; McKernan et al., 2009), we are able to precisely measure an income shock in the form of a delayed large lump sum payment. Lastly, as other studies on the federal EITC have primarily examined outcomes relating to employment (Hoynes \& Patel, 2018), poverty (Meyer, 2010), or health (Averett \& Wang, 2013), this study extends the EITC literature by examining previously unexplored household hardships in the months after tax filing.

Despite this study's contributions to the literature, this work is not without its limitations. First, while tax filers claiming the EITC or the ACTC were instructed not to expect their tax refunds until the week of February 27, we cannot precisely determine the actual length of delays in refund receipt experienced by early filers in our sample, though Aladangady et al., 2018) find that EITC payments after the PATH Act peaked about 2 weeks later than prior years. Second, this study reports only the immediate effects of the PATH Act in the six months post-filing: It is unclear whether the adverse impact on household hardships would persist in the long run or whether EITC filers would adjust their financial and tax filing behaviours over time to avoid the negative effects of the reform. Third, this analysis focuses only on EITC recipients and does not provide evidence on the impact of the new provision for households that claimed but did not receive the EITC or the ACTC as well as those who received the ACTC but not the EITC. However, since less than $1 \%$ of sampled lower-income filers received the ACTC without receiving the EITC, the latter issue 
is unlikely to be a concern in this research. Relatedly, a limitation of this study is that our sample of EITC recipients represents a specific group of tax filers who used TTFE to complete their taxes and does not include EITC recipients that filed taxes in other ways, such as through Volunteer Income Tax Assistance sites or by using paid tax preparers or non-TTFE online tax software services. Compared to the general population of EITC recipients in 2016, our sample consists of a higher proportion of households without claimed dependents, and the average EITC amount in our sample is substantially lower than the national average (Falk \& Crandall-Hollick, 2018). As such, there are limitations to the generalizability of our findings to the full population of EITC recipients. Lastly, the current analysis may not appropriately account for the effect of state tax refunds. While in most cases, state tax refunds tend to be substantially smaller than the federal refund, it can still be a substantial windfall for many households. Given that the PATH Act rules did not target state tax refunds and states have different timelines for issuing the refunds to e-filers, receiving state tax refunds could provide substantial financial relief to households waiting for their federal refund. While our regression models control for the amount of state refund received, they may fail to completely account for the significance of state tax refunds to the financial security of households affected by the PATH Act rules.

\section{Conclusion}

In an effort to reduce fraudulent EITC and ACTC claims, policymakers built a delay into refund disbursements for EITC/ACTC claimants as part of the PATH Act. This resulted in almost 11 million low-wage working families facing refund payment delays early in the 2019 tax filing season (Treasury Inspector General for Tax Administration, 2019), and our study documents that this delay increased the likelihood of these households experiencing food insecurity. As this study only examined a subset of potential household outcomes that could be affected by payment delays, it is possible that the true welfare costs of these delays are higher than what is implied by our study. For example, Maag et al. (2016) found that tax filers commonly reported that a delay in receiving their refunds would lead them to delay paying debts or past due bills, miss housing payments or other essential bill payments, and overdraft accounts, all of which can carry substantial costs in terms of fees, interest, damage to credit scores, and risk of eviction or utility shut-offs.

Though reducing tax fraud in any form is an important policy goal, the benefits of delayed EITC payments appear somewhat nebulous. To our knowledge, no formal cost-benefit analysis of the PATH Act exists, but we do know that in the first month of the 2019 tax season only $0.03 \%$ of delayed tax returns (or roughly $\$ 12$ million in payments) were determined to be fraudulent (Treasury Inspector General for Tax Administration, 2019). This represents an infinitesimally small fraction of broader tax evasion costs (Gale \& Krupkin, 2019). Given the observed impacts of the delayed payments in both this study and Aladangady et al. (2018), policymakers should consider whether the benefits of delayed refunds outweigh the costs. 


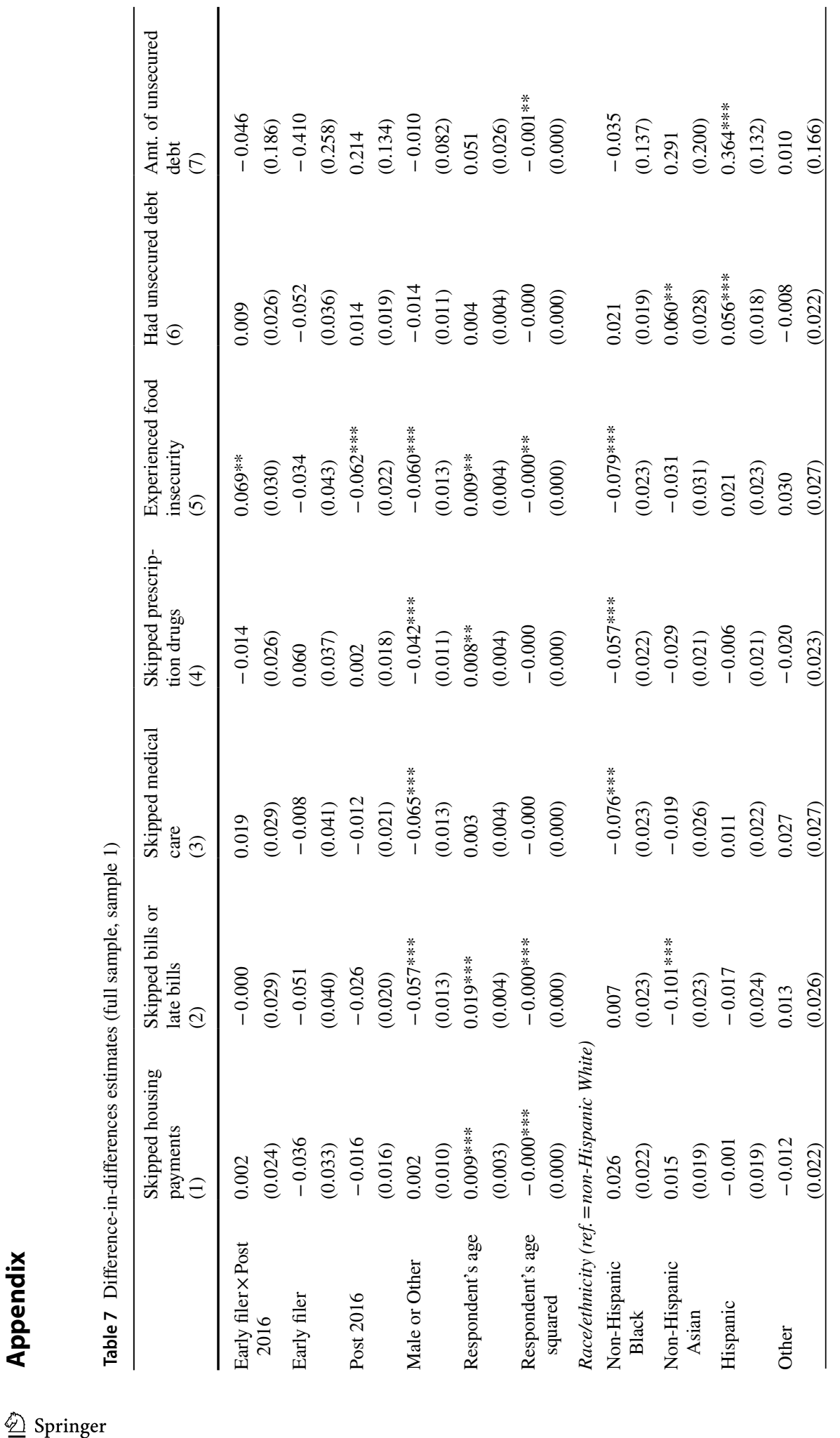




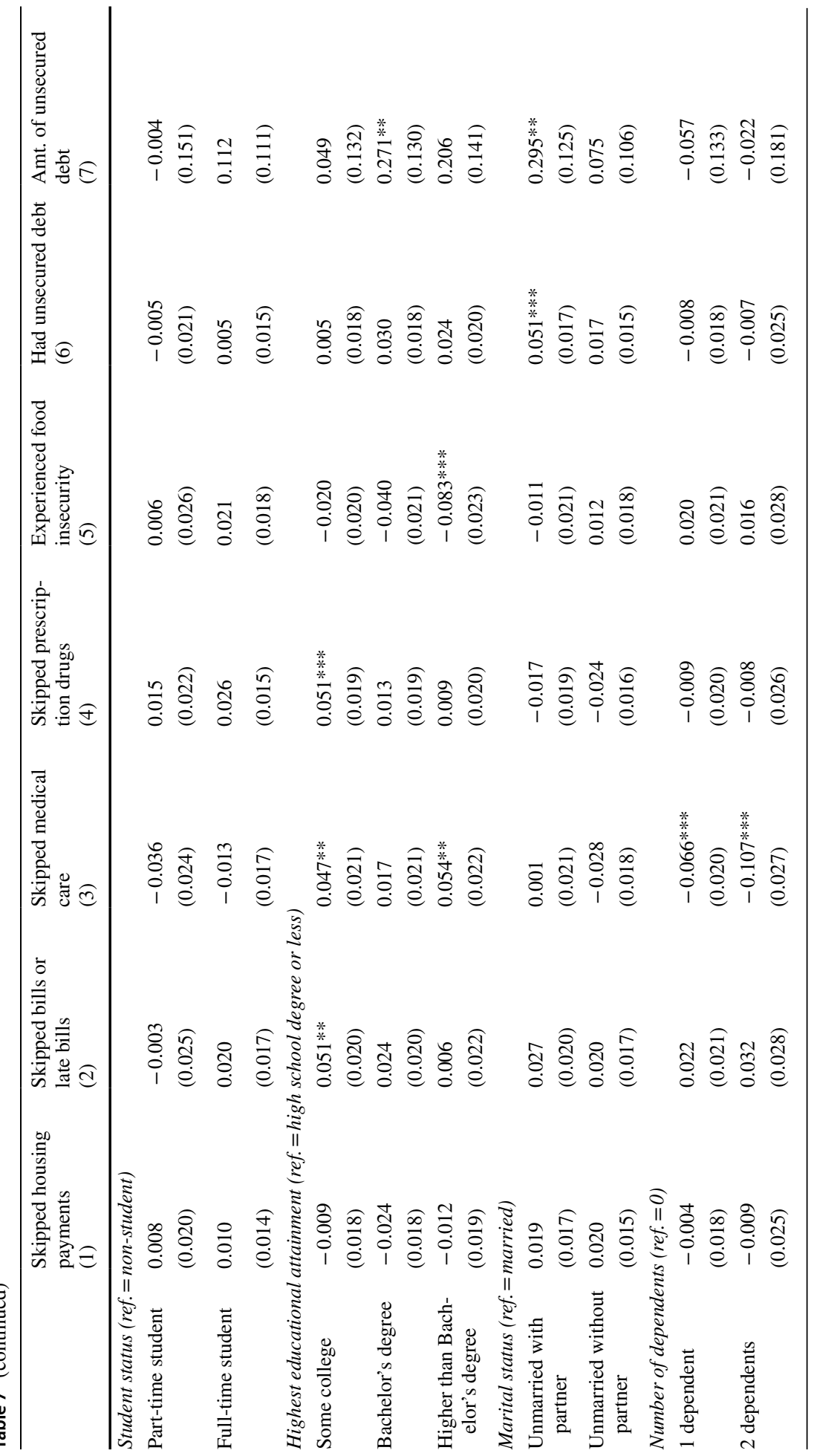




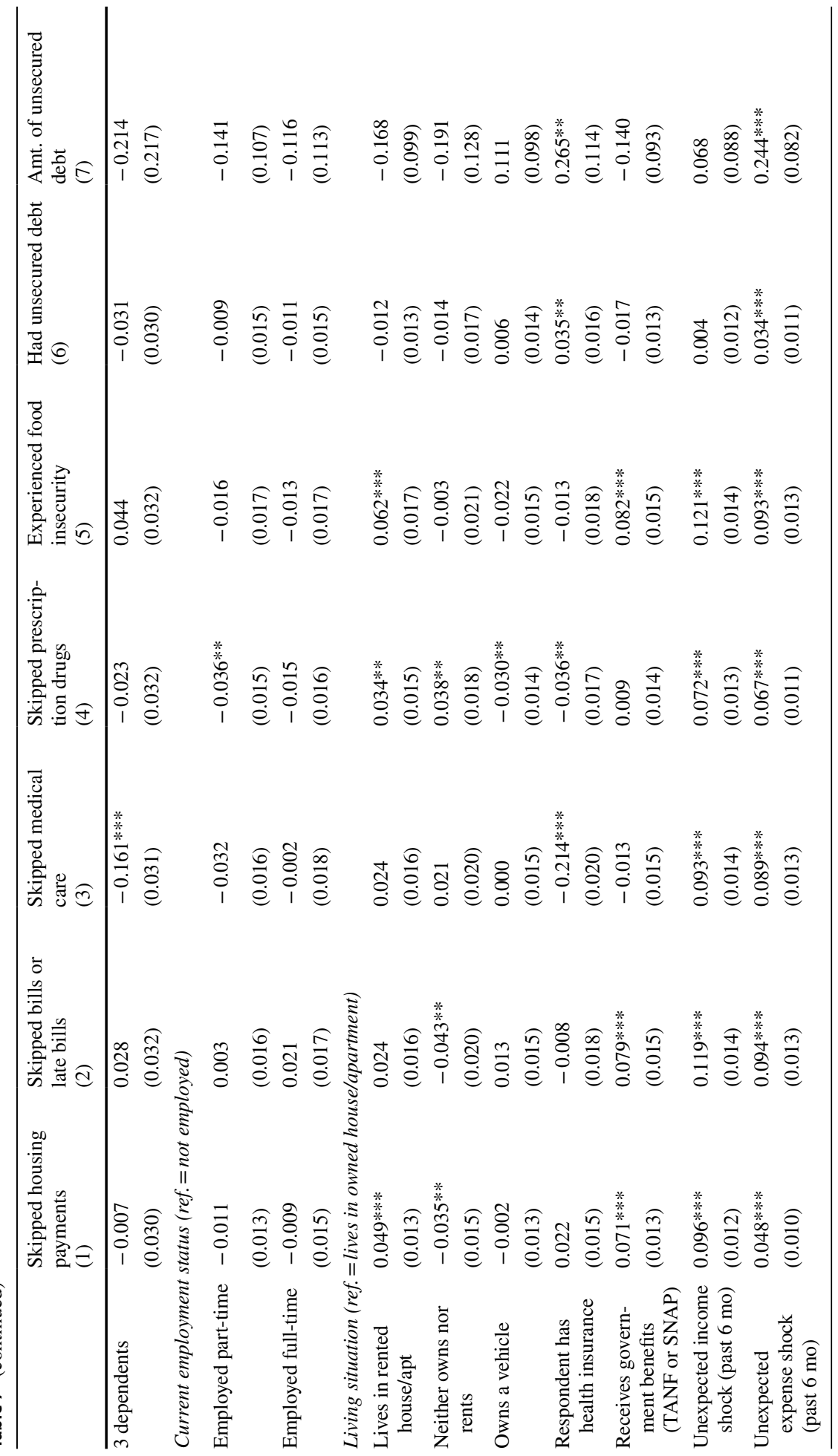




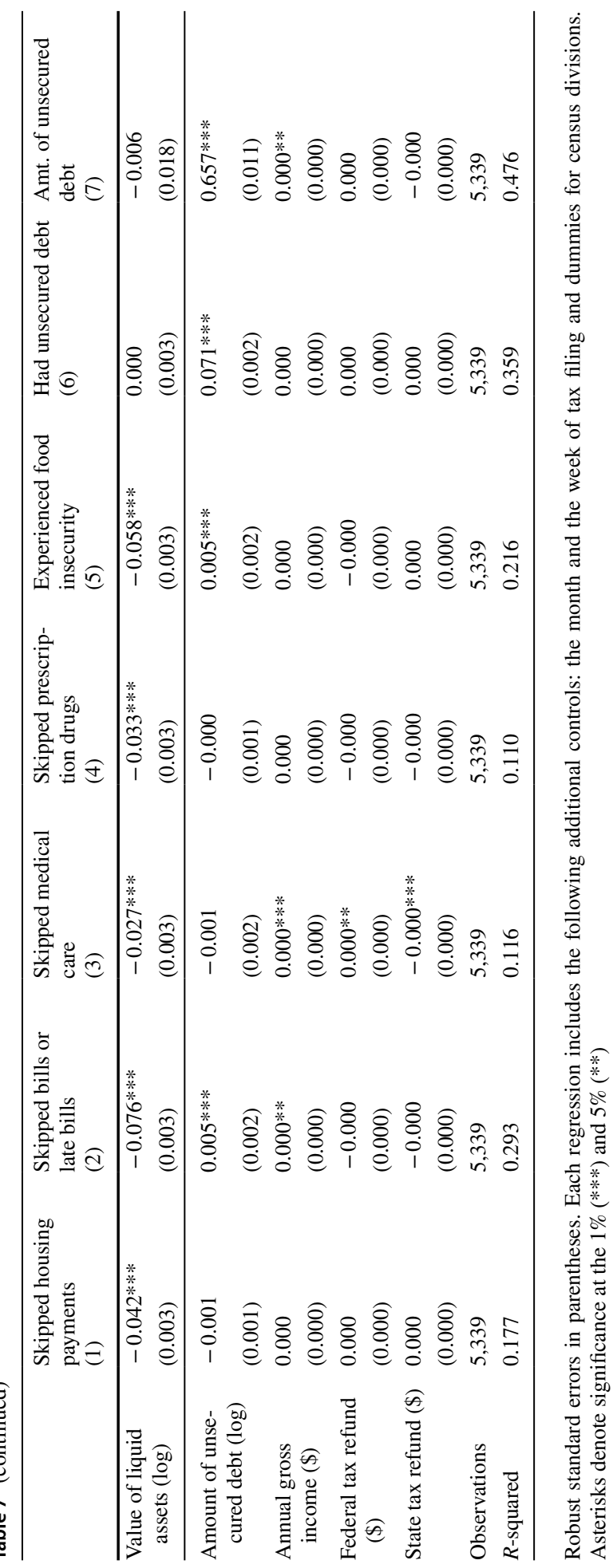




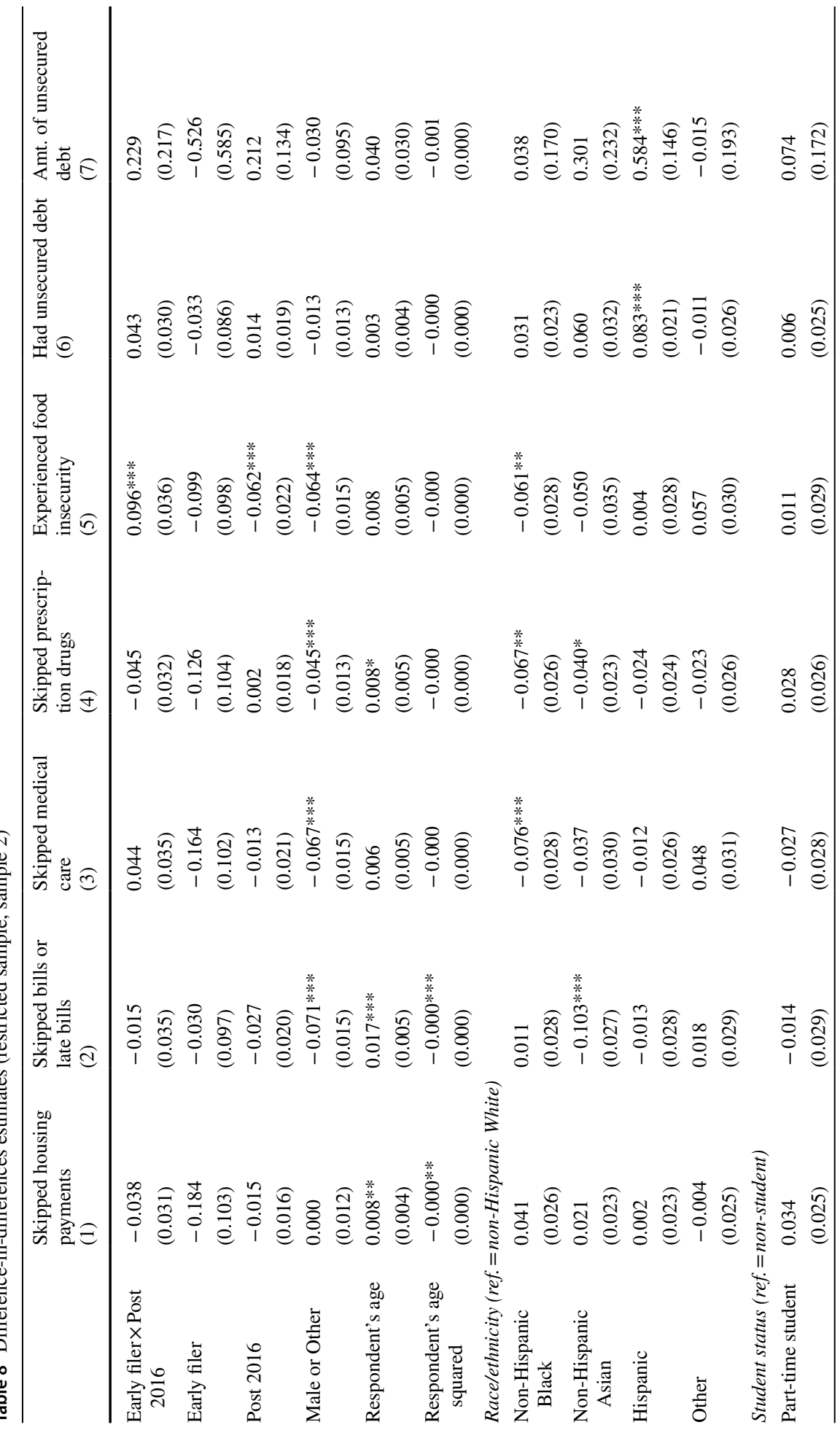




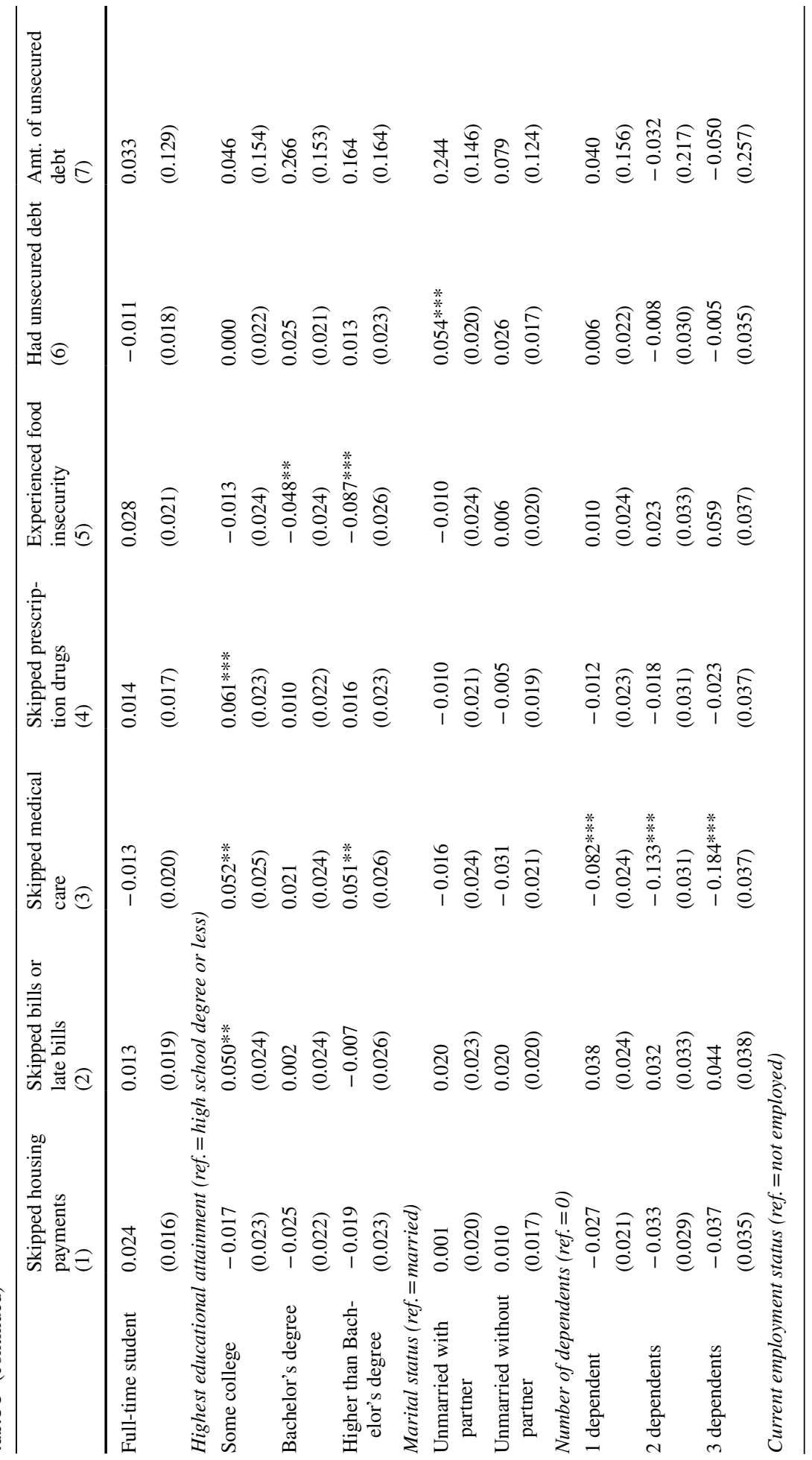




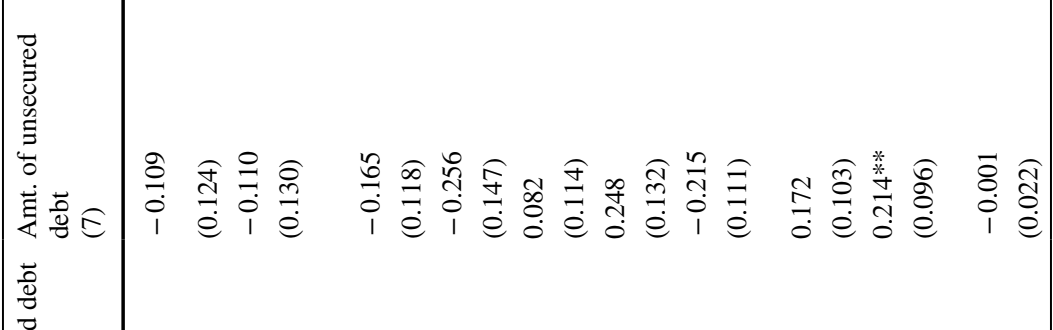

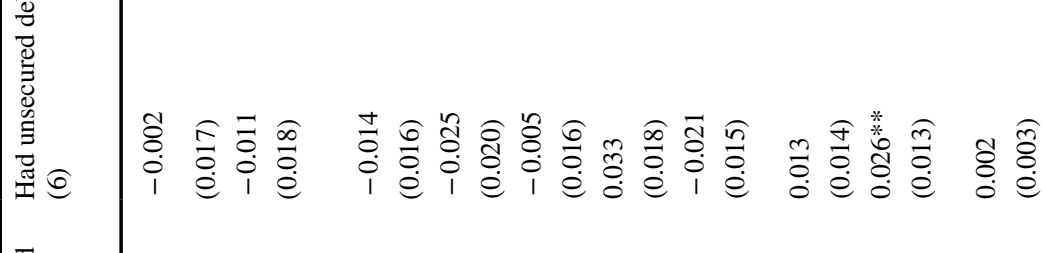

$$
\begin{aligned}
& 8
\end{aligned}
$$

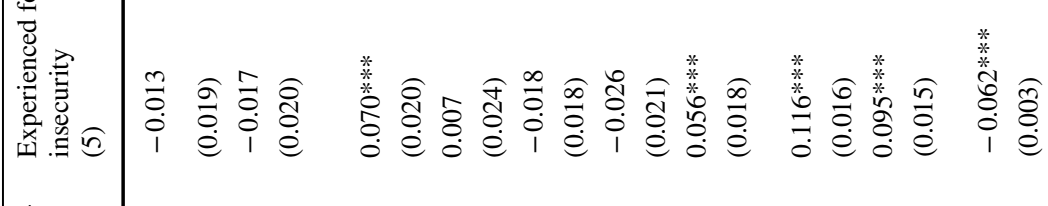

$$
\begin{aligned}
& \text { 完 }
\end{aligned}
$$

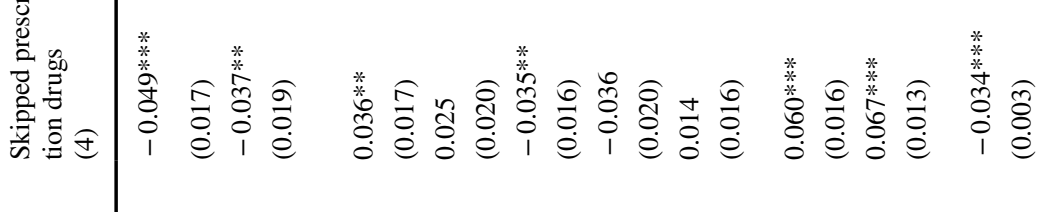

$$
\begin{aligned}
& \text { تี }
\end{aligned}
$$

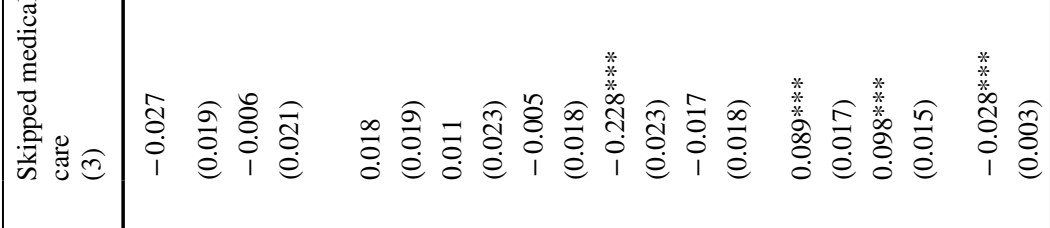

$$
\begin{aligned}
& \text { ᄒำ }
\end{aligned}
$$

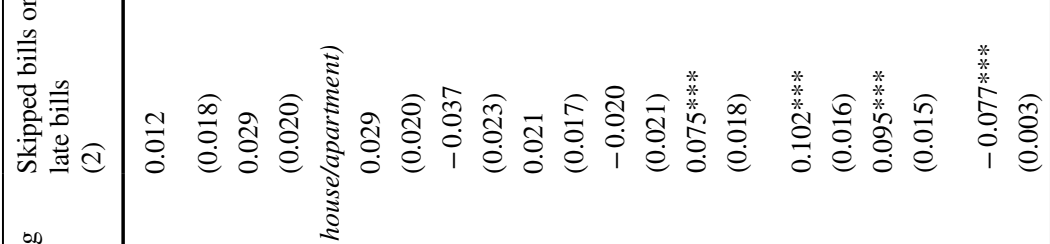

$$
\begin{aligned}
& \text { 我 }
\end{aligned}
$$

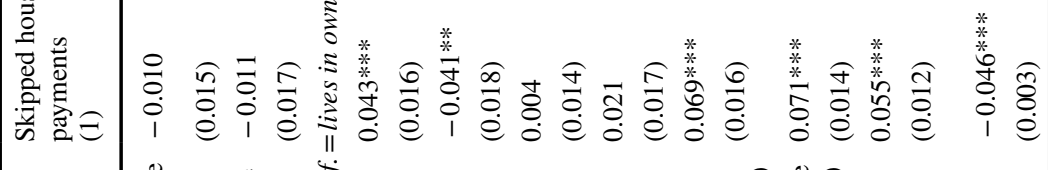

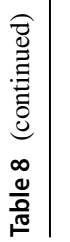

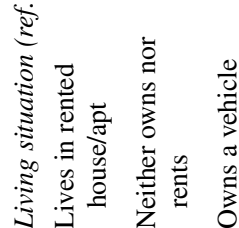

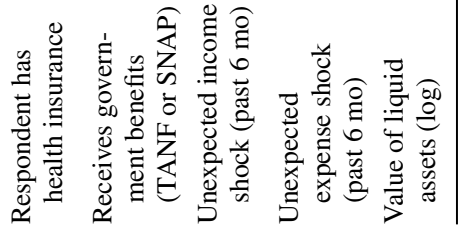




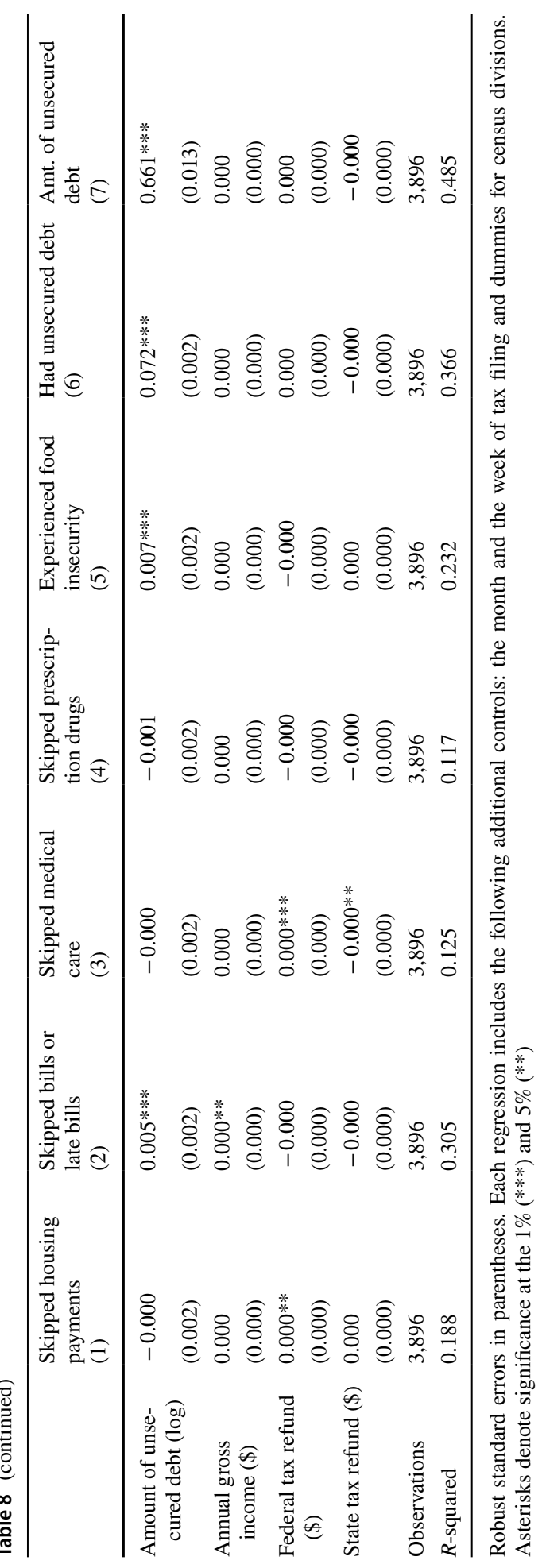


Funding This paper received no direct financial support from any source. The broader initiative on tax-time savings and financial well-being, of which this research project is one component, received outside funding from these sources: the U.S. Department of Treasury, the Annie E. Casey Foundation, the Intuit Financial Freedom Foundation, and the JPMorgan Chase Foundation. These organizations provided grant funding that partially covered the authors' salaries, the general collection of data (e.g., survey participation rewards), processing of data, and data analysis.

Data Availability Our paper uses proprietary administrative tax data and data from a survey of low-income households that include detailed information about respondents' finances and individual-level tax data. Given the sensitivity of these data, we cannot make them publicly available. However, interested researchers can access these data by contacting the Washington University research team and formally receiving permission from the Washington University Institutional Review Board.

Code Availability The code used in this study is available upon request.

\section{Declarations}

Conflict of Interest The authors declare no competing interests.

Ethics Approval All procedures performed in studies involving human participants were in accordance with the ethical standards of the institutional review board of Washington University in St. Louis and with the 1964 Helsinki declaration and its later amendments or comparable ethical standards.

Consent to Participate Informed consent was obtained from all individual participants included in the study.

Disclaimer Statistical compilations disclosed in this document relate directly to the bona fide research of, and public policy discussions concerning, financial security of individuals and households as it relates to the tax filing process and more generally. Compilations follow Intuit's protocols to help ensure the privacy and confidentiality of customer tax data.

\section{References}

Acs, G., Loprest, P., \& Nichols, A. (2009). Risk and recovery: Documenting the changing risks to family incomes. Perspectives on Low-Income Working Families, Brief 9. The Urban Institute. https://www. urban.org/sites/default/files/publication/32966/411890-risk-and-recovery-documenting-the-changingrisks-to-family-incomes.pdf. Accessed 7 Jan 2022.

Aladangady, A., Aron-Dine, S., Cashin, D., Dunn, W., Feiveson, L., Lengermann, P., Richard, K., \& Sahm, C. (2018). High-frequency spending responses to the Earned Income Tax Credit. FEDS Notes. https:// doi.org/10.17016/2380-7172.2199. Accessed 7 Jan 2022.

Averett, S., \& Wang, Y. (2013). The effects of Earned Income Tax Credit payment expansion on maternal smoking. Health Economics, 22(11), 1344-1359. https://doi.org/10.1002/hec.2886

Baker, S. R., \& Yannelis, C. (2017). Income changes and consumption: Evidence from the 2013 federal government shutdown. Review of Economic Dynamics, 23, 99-124. https://doi.org/10.1016/j.red.2016. 09.005

Barr, M. S. (2007). An inclusive, progressive national savings and financial services policy. Harvard Law \& Policy Review, 1(1), 161-184.

Bellisle, D., \& Marzahl, D. (2015). Restructuring the EITC: A credit for the modern worker. Center for Economic Progress Report.

Blank, R. M., \& Barr, M. S. (2009). Insufficient funds: Savings, assets, credit, and banking among lowincome households. Russell Sage Foundation.

Board of Governors of the Federal Reserve System. (2016). Report on the economic well-being of U.S. households in 2015. https://www.federalreserve.gov/2015-report-economic-well-being-us-households201605.pdf. Accessed 7 Jan 2022.

Center on Budget and Policy Priorities. (2019). Policy basics: The Earned Income Tax Credit. https://www. cbpp.org/research/federal-tax/policy-basics-the-earned-income-tax-credit. Accessed 7 Jan 2022. 
Chase, S., Gjertson, L., Collins, J. M., Chase, S., Jertson, L. G., \& Collins, J. M. (2011). Coming up with cash in a pinch: Emergency savings and its alternatives http://citeseerx.ist.psu.edu/viewdoc/summary? doi=10.1.1.369.4498

Clayton, M., Liñares-Zegarra, J., \& Wilson, J. O. S. (2015). Does debt affect health? Cross country evidence on the debt-health nexus. Social Science and Medicine, 130, 51-58. https://doi.org/10.1016/j. socscimed.2015.02.002

Collins, J. M., \& Gjertson, L. (2013). Emergency savings for low-income consumers. Focus, 30(1), 12-17.

Dahl, G. B., \& Lochner, L. (2012). The impact of family income on child achievement: Evidence from the Earned Income Tax Credit. American Economic Review, 102(5), 1927-1956. https://doi.org/10.1257/ aer.102.5.1927

Desmond, M., \& Kimbro, R. T. (2015). Eviction's fallout: Housing, hardship, and health. Social Forces, 94(1), 295-324. https://doi.org/10.1093/sf/sov044

Despard, M. R., Guo, S., Grinstein-Weiss, M., Russell, B., Oliphant, J. E., \& Deruyter, A. (2018). The mediating role of assets in explaining hardship risk among households experiencing financial shocks. Social Work Research, 42(3), 147-158. https://doi.org/10.1093/swr/svy012

Despard, M. R., Perantie, D. C., Oliphant, J., \& Grinstein-Weiss, M. (2015). Do EITC recipients use their tax refunds to get ahead? Evidence from the Refund to Savings initiative (CSD Research Brief No. 15-38). Center for Social Development. https://doi.org/10.7936/K7610ZV7

Despard, M., Grinstein-Weiss, M., Chun, Y., \& Roll, S. (2020). COVID-19 job and income loss leading to more hunger and financial hardship. Brookings Institution, Washington, DC. Retrieved from: https:// www.brookings.edu/blog/up-front/2020/07/13/covid-19-job-and-income-loss-leading-to-more-hungerandfinancial-hardship/

Eissa, N., \& Liebman, J. B. (1996). Labor supply response to the Earned Income Tax Credit. The Quarterly Journal of Economics, 111(2), 605-637. https://doi.org/10.2307/2946689

Ellwood, D. T. (2000). The impact of the Earned Income Tax Credit and social policy reforms on work, marriage, and living arrangements. National Tax Journal, 53(4), 1063-1105.

Epley, N., \& Gneezy, A. (2007). The framing of financial windfalls and implications for public policy. Journal of Socio-Economics, 36(1), 36-47. https://doi.org/10.1016/j.socec.2005.12.012

Evans, W. N., \& Garthwaite, C. L. (2014). Giving mom a break: The impact of higher EITC payments on maternal health. American Economic Journal: Economic Policy, 6(2), 258-290. https://doi.org/10. 1257/pol.6.2.258

Falk, G., \& Crandall-Hollick, M. L. (2018). The Earned Income Tax Credit (EITC): An Overview. Washington, D.C.: Congressional Research Service.

Gale, W., \& Krupkin, A. (2019). How big is the problem of tax evasion? https://www.brookings.edu/blog/ up-front/2019/04/09/how-big-is-the-problem-of-tax-evasion/. Accessed 7 Jan 2022.

Gelman, M., Kariv, S., Shapiro, M. D., Silverman, D., \& Tadelis, S. (2018). How individuals respond to a liquidity shock: Evidence from the 2013 government shutdown. Journal of Public Economics, 189. https://doi.org/10.1016/j.jpubeco.2018.06.007

Gershoff, E. T., Aber, J. L., Raver, C. C., \& Lennon, M. C. (2007). Income is not enough: Incorporating material hardship into models of income associations with parenting and child development. Child Development, 78(1), 70-95. https://doi.org/10.1111/j.1467-8624.2007.00986.x

Gertler, P., Martinez, S., Rawlings, L. B., Premand, P., \& Vermeersch, C. M. J. (2016). Impact evaluation in practice: Second edition. World Bank Group.

Greenstein, R., Wancheck, J., \& Marr, C. (2019). Reducing overpayments in the Earned Income Tax Credit. https://www.cbpp.org/research/federal-tax/reducing-overpayments-in-the-earned-income-tax-credit. Accessed 7 Jan 2022.

Grinstein-Weiss, M., Perantie, D. C., Russell, B. D., Comer, K., Taylor, S. H., Luo, L., Key, C., \& Ariely, D. (2015). Refund to Savings 2013: Comprehensive report on a large-scale tax-time saving program (CSD Research Report No. 15-06). https://doi.org/10.7936/K7280749

Gundersen, C., \& Ziliak, J. P. (2004). Poverty and macroeconomic performance across space, race, and family structure. Demography, 41(1), 61-86. https://doi.org/10.1353/dem.2004.0004

Hardy, B., Smeeding, T., \& Ziliak, J. P. (2018). The changing safety net for low-income parents and their children: Structural or cyclical changes in income support policy? Demography, 55(1), 189-221. https://doi.org/10.1007/s13524-017-0642-7

Heflin, C. (2016). Family instability and material hardship: Results from the 2008 survey of income and program participation. Journal of Family and Economic Issues, 37(3), 359-372. https://doi.org/10. 1007/s10834-016-9503-6

Heflin, C., \& Iceland, J. (2009). Poverty, material hardship, and depression. Social Science Quarterly, 90(5), 1051-1071. https://doi.org/10.1111/j.1540-6237.2009.00645.x 
Heflin, C., London, A. S., \& Scott, E. K. (2011). Mitigating material hardship: The strategies low-income families employ to reduce the consequences of poverty. Sociological Inquiry, 81(2), 223-246. https:// doi.org/10.1111/j.1475-682X.2011.00369.x

Holt, S. (2015). Periodic payment of the Earned Income Tax Credit revisited. https://www.brookings.edu/ research/periodic-payment-of-the-earned-income-tax-credit-revisited/

Hotz, V. J., Mullin, C. H., \& Scholz, J. K. (2006). Examining the effect of the Earned Income Tax Credit on the labor market participation of families on welfare. NBER Working Paper 11968.

Hoynes, H., Miller, D., \& Simon, D. (2015). Income, the Earned Income Tax Credit, and infant health. Economic Journal: Economic Policy, 7(1), 172-211.https://doi.org/10.1257/pol.20120179.

Hoynes, H., \& Patel, A. J. (2018). Effective policy for reducing poverty and inequality? The Earned Income Tax Credit and the distribution of income. Journal of Human Resources, 53(4), 859-890. https://doi. org/10.3368/jhr.53.4.1115.7494R1

Internal Revenue Service. (2018a). EITC fast facts. https://www.eitc.irs.gov/partner-toolkit/basic-marketingcommunication-materials/eitc-fast-facts/eitc-fast-facts. Accessed 7 Jan 2022.

Internal Revenue Service. (2018b). New federal tax law may affect some refunds filed in early 2017; IRS to share details widely with taxpayers starting this summer. https://www.irs.gov/tax-professionals/newfederal-tax-law-may-affect-some-refunds-filed-in-early-2017. Accessed 7 Jan 2022.

Internal Revenue Service. (2019a). 2017 tax filing season opens today. https://www.irs.gov/newsroom/ 2017-tax-filing-season-opens-today. Accessed 7 Jan 2022.

Internal Revenue Service. (2019c). PATH Act tax related provisions. https://www.irs.gov/newsroom/pathact-tax-related-provisions. Accessed 7 Jan 2022).

Internal Revenue Service. (2019b). Internal Revenue Service data book, 2018. https://www.irs.gov/pub/irspdf/p55b.pdf. Accessed 7 Jan 2022.

Jones, L. E., \& Michelmore, K. (2018). The impact of the Earned Income Tax Credit on household finances. Journal of Policy Analysis and Management, 37(3), 521-545.

Leete, L., \& Bania, N. (2010). The effect of income shocks on food insufficiency. Review of Economics of the Household, 8(4), 505-526. https://doi.org/10.1007/s11150-009-9075-4

Legislative Analyst's Office. (2018). California Earned Income Tax Credit education and outreach. https:// lao.ca.gov/Publications/Report/3826. Accessed 7 Jan 2022.

Leibel, K. (2014). Taxpayer compliance and sources of error for the Earned Income Tax Credit claimed on 2006-2008 returns. https://www.irs.gov/pub/irs-soi/15rpeitctaxpayercompliancetechpaper.pdf. Accessed 7 Jan 2022.

Maag, E., Roll, S. P., \& Oliphant, J. E. (2016). Delaying tax refunds for Earned Income Tax Credit and Additional Child Tax Credit claimants. https://www.urban.org/sites/default/files/publication/86336/ 2001018-delaying-tax-refunds-for-earned-income-tax-credit-and-additional-child-tax-credit-claim ants_0.pdf. Accessed 7 Jan 2022.

Manoli, D., \& Turner, N. (2018). Cash-on-hand and college enrollment: Evidence from population tax data and the Earned Income Tax Credit. American Economic Journal: Economic Policy, 10(2), 242-271. https://doi.org/10.1257/pol.20160298

McGranahan, L., \& Schanzenbach, D. W. (2013). The Earned Income Tax Credit and food consumption patterns (FRB of Chicago Working Paper No. 2013-14). Available at SSRN: https://doi.org/10.2139/ssrn. 2366846. Accessed 7 Jan 2022).

McKernan, S., Ratcliffe, C., \& Vinopal, K. (2009). Do assets help families cope with adverse events? In Washington, DC: Urban Institute (Issue January 2000). http://www.urban.org/UploadedPDF/411994_ help_family_cope.pdf?RSSFeed=UI_PovertyandSafetyNet.xml. Accessed 7 Jan 2022.

Mendenhall, R., Edin, K., Crowley, S., Sykes, J., Tach, L., Kriz, K., \& Kling, J. R. (2012). The role of Earned Income Tax Credit in the budgets of low-income households. Social Service Review, 86(3), 367-400. https://doi.org/10.1086/667972

Meyer, B. D., \& Rosenbaum, D. T. (2001). Welfare, the Earned Income Tax Credit, and the labor supply of single mothers. Quarterly Journal of Economics, 116(3), 1063-1114. https://doi.org/10.1162/00335 530152466313

Meyer, B. D. (2010). The effects of the Earned Income Tax Credit and recent reforms executive summary. In Brown, J. R. (ed.) Tax Policy and the Economy (Vol. 24, pp. 153-180). www.nber.org/chapters/c11973

Morduch, J., \& Schneider, R. (2017). The financial diaries. Princeton University Press.

Mullainathan, S., \& Shafir, E. (2009). Savings policy and decisionmaking in low-income households. In M. R. Blank, \& M. S Barr (Eds.), Insufficient funds: Savings, assets, credit, and banking among lowincome households (pp. 121-146). Russell Sage Foundation.

Mullainathan, S., \& Shafir, E. (2013). Scarcity: Why having too little means so much. Macmillan.

Neuberger, Z., Greenstein, R., \& Orszag, P. (2006). Barriers to saving. Communities and Banking, Sum, 25-27. https://ideas.repec.org/a/fip/fedbcb/y2006isump25-27.html. Accessed 7 Jan 2022. 
O'Brien, R. (2008). Ineligible to save? Asset limits and the saving behavior of welfare recipients. Journal of Community Practice, 16(2), 183-199. https://doi.org/10.1080/10705420801998003

Palar, K., Laraia, B., Tsai, A. C., Johnson, M. O., \& Weiser, S. D. (2016). Food insecurity is associated with HIV, sexually transmitted infections and drug use among men in the United States. AIDS, 30(9), 1457-1465. https://doi.org/10.1097/QAD.0000000000001095

Perez-Lopez, D. J. (2021). Economic hardship declined in households with children as Child Tax Credit payments arrived. United States Census Bureau. https://www.census.gov/library/stories/2021/08/ economic-hardship-declined-in-households-with-children-as-child-tax-credit-payments-arrived.html. Accessed 7 Jan 2022.

Ratcliffe, C., McKernan, S.-M., \& Zhang, S. (2011). How much does the supplemental nutrition assistance program reduce food insecurity? American Journal of Agricultural Economics, 93(4), 1082-1098. https://doi.org/10.1093/ajae/aar026

Rauh, V. A., Whyatt, R. M., Garfinkel, R., Andrews, H., Hoepner, L., Reyes, A., Diaz, D., Camann, D., \& Perera, F. P. (2004). Developmental effects of exposure to environmental tobacco smoke and material hardship among inner-city children. Neurotoxicology and Teratology, 26(3), 373-385. https://doi.org/ 10.1016/j.ntt.2004.01.002

Rehkopf, D. H., Strully, K. W., \& Dow, W. H. (2014). The short-term impacts of Earned Income Tax Credit disbursement on health. International Journal of Epidemiology, 43(6), 1884-1894.

Roll, S. P., Davison, G., Grinstein-Weiss, M., Despard, M. R., \& Bufe, S. (2018). Refund to savings 20152016: Field experiments to promote tax-time saving in low-and moderate-income households (CSD Research Report No. 18-28). https://doi.org/10.7936/K72J6BD5. Accessed 7 Jan 2022.

Roll, S., Chun, Y., Brugger, L., \& Hamilton, L. (2021). How are American families using their Child Tax Credit payments? Evidence from Census data. Social Policy Institute Research. https://cpb-us-w2. wpmucdn.com/sites.wustl.edu/dist/a/2003/files/2021/09/CTC-National-Analysis.pdf. Accessed 7 Jan 2022.

Romich, J. L., \& Weisner, T. (2000). How families view and use the EITC: Advance payment versus lump sum delivery. National Tax Journal, 53(4), 1245-1265.

Schanzenbach, D. W., Nunn, R., Bauer, L., \& Mumford, M. (2016). Where does all the money go: Shifts in household spending over the past 30 years. https:/www.brookings.edu/wp-content/uploads/2016/08/ where_does_all_the_money_go.pdf. Accessed 7 Jan 2022.

Searle, B. A., \& Köppe, S. (2014). Assets, savings and wealth, and poverty: A review of evidence. Final report to the Joseph Rowntree Foundation. Bristol: Personal Finance Research Centre. https://www. bristol.ac.uk/media-library/sites/geography/pfrc/pfrc1405-assets-savings-wealth-poverty.pdf. Accessed 7 Jan 2022.

Shaefer, H. L., Song, X., \& Williams Shanks, T. R. (2013). Do single mothers in the United States use the Earned Income Tax Credit to reduce unsecured debt? Review of Economics of the Household, 11(4), 659-680. https://doi.org/10.1007/s11150-012-9144-y

Shah, A. K., Mullainathan, S., \& Shafir, E. (2012). Some consequences of having too little. Science, 338(6107), 682-685. https://doi.org/10.1126/science.1222426

Sherraden, M., \& Barr, M. S. (2005). Institutions and inclusion in saving policy. Building Assets, Building Credit: Creating Wealth in Low-Income Communities, 2012(2004), 1-50.

Sullivan, J. X., Turner, L., \& Danziger, S. (2008). The relationship between income and material hardship. Journal of Policy Analysis and Management, 27(1), 63-81. https://doi.org/10.1002/pam.20307

Sykes, J., Križ, K., Edin, K., \& Halpern-Meekin, S. (2015). Dignity and dreams: What the Earned Income Tax Credit (EITC) means to low-income families. American Sociological Review, 80(2), 243-267. https://doi.org/10.1177/0003122414551552

Tach, L. M., \& Greene, S. S. (2014). Robbing Peter to pay Paul : Economic and cultural explanations for how lower-income families manage debt. Social Problems, 61(1), 1-21.

The Aspen Institute. (2018). Five charts that illustrate the size and scope of consumer debt. https://www. aspeninstitute.org/blog-posts/size-and-scope-of-consumer-debt/. Accessed 7 Jan 2022.

Treasury Inspector General for Tax Administration. (2019). Interim results of the 2019 filing season. https:// www.treasury.gov/tigta/auditreports/2019reports/201944030fr.pdf. Accessed 7 Jan 2022.

Treasury Inspector General for Tax Administration. (2018). Results of the 2018 filing season. https://www. treasury.gov/tigta/auditreports/2019reports/201940013_oa_highlights.html. Accessed 7 Jan 2022.

The Pew Charitable Trusts. (2015). The complex story of American debt: Liabilities in family balance sheets. https://www.pewtrusts.org/en/research-and-analysis/reports/2015/07/the-complex-story-ofamerican-debt. Accessed 7 Jan 2022.

United States Department of Agriculture (2012) "U.S. Household Food Security Survey Module: Six-Item Short Form”. Economic Research Service. https:/www.ers.usda.gov/media/8282/short2012.pdf 
Whittle, H. J., Palar, K., Hufstedler, L. L., Seligman, H. K., Frongillo, E. A., \& Weiser, S. D. (2015). Food insecurity, chronic illness, and gentrification in the San Francisco Bay Area: An example of structural violence in United States public policy. Social Science and Medicine, 143, 154-161. https://doi.org/10. 1016/j.socscimed.2015.08.027

Publisher's Note Springer Nature remains neutral with regard to jurisdictional claims in published maps and institutional affiliations. 